Spillovers of U.S. Unconventional Monetary Policy to Emerging Markets: The Role of Capital Flows

Pablo Anaya

Michael Hachula

Christian Offermanns

School of Business \& Economics

Discussion Paper

Economics

$2015 / 35$ 


\title{
Spillovers of U.S. Unconventional Monetary Policy to Emerging Markets: The Role of Capital Flows*
}

\author{
Pablo Anaya ${ }^{\dagger} \quad$ Michael Hachula ${ }^{\ddagger} \quad$ Christian Offermanns ${ }^{\S}$
}

This version: November 2, 2015

\begin{abstract}
A growing literature stresses the importance of the "global financial cycle", a common global movement in asset prices and credit conditions, for emerging market economies (EMEs). It is argued that one of the key drivers of this global cycle is monetary policy in the U.S., which is transmitted through international capital flows. In this paper, we add to this discussion and investigate empirically whether U.S. unconventional monetary policy (UMP) between 2008 and 2014 is related to financial conditions in EMEs, and, whether it is transmitted through portfolio flows. We find that a U.S. UMP shock significantly increases portfolio flows from the U.S. to EMEs for almost two quarters. The rise in inflows is accompanied by a persistent increase in several real and financial variables in EMEs. Moreover, we find that, on average, EMEs reacted with an easing of their own monetary policy stance in response to an expansionary U.S. shock.
\end{abstract}

JEL Classification: C54, E52, F42.

Keywords: Unconventional monetary policy, International capital flows, Global financial cycle, Global VAR, Trilemma vs. dilemma.

${ }^{*}$ We thank Sandra Eickmeier as well as seminar participants at the Deutsche Bundesbank, the DIW Berlin, and the Freie Universität Berlin for helpful comments and suggestions.

${ }^{\dagger}$ German Institute for Economic Research (DIW Berlin), Graduate Center, and Freie Universität Berlin, panaya@diw.de

${ }^{\ddagger}$ German Institute for Economic Research (DIW Berlin), Graduate Center, and Freie Universität Berlin, mhachula@diw.de

§Institute for Employment Research (IAB), Nuremberg, christian.offermanns@iab.de. 


\section{Introduction}

In response to the global financial crisis, the Federal Reserve Bank engaged in several measures of unconventional monetary policy (UMP), in particular in large scale asset purchase programs, often termed "quantitative easing". At the same time, large and volatile capital flows into emerging market economies (EMEs) have reinforced a debate on the determinants and consequences of these cross-border flows. ${ }^{1}$ We contribute to this debate by empirically investigating the effect of U.S. unconventional monetary policy on international capital flows and the role of capital flows in transmitting U.S. policy to real and financial conditions in emerging market economies.

The discussion about cross-border capital flows is linked to a growing literature on the "global financial cycle" as a key determinant of capital flows into EMEs (see, among others, Rey, 2013, or, Passari and Rey, 2015). This global financial cycle is described as common movements in gross capital flows, credit conditions, and asset prices globally across countries. In a seminal study, Rey (2013) argues that a main driver of this global cycle is monetary policy in the center country, the U.S., which is transmitted through international capital flows. As a consequence, Rey claims that, in this case, the classical "trilemma" between independent MP, free capital flows, and a fixed exchange rate is reduced to a "dilemma": even if exchange rates are floating, an open capital account restricts monetary policy independence. ${ }^{2}$ Passari and Rey (2015) provide empirical evidence for the existence of a global financial cycle. They show that prices of stocks and other risky assets as well as credit, leverage and gross capital flows around the world are related to one global component. In line with the idea of a "dilemma", the correlations between countries do not vary systematically with exchange rate regimes.

Regarding the role of U.S. monetary policy, however, Passari and Rey (2015) present evidence only for an effect on financial conditions in one specific country, namely the UK. In related research, Miranda Agrippino and Rey (2014) show that conventional U.S. monetary policy is linked to a global factor in risky asset prices, cross-border credit flows and in particular to U.S. and European banks leverage. In the same vein, Bruno and Shin (2015a) find a link between U.S. MP and international banking flows for 1995 - 2007. While these studies show the importance of banking flows in transmitting U.S. monetary policy before the financial crisis, Shin (2013) presents evidence that since 2008 international banking flows strongly diminished. Instead, bond and equity flows to EMEs increased heavily. ${ }^{3}$

\footnotetext{
${ }^{1}$ Policy makers in EMEs fear that large and volatile inflows may exert negative effects on their domestic economies like appreciation pressure on the currency, financial imbalances, or even an over-heating of the economy, and increase the likelihood of sudden flow reversals (sudden stops). These concerns are not unwarranted. Gourinchas and Obstfeld (2012), for instance, show that large capital inflows can lead to strong movements in exchange rates, making macroeconomic policy more difficult, and can induce financial crises in the event of a sudden stop.

${ }^{2}$ Another version of Rey's study was published in 2015 . Henceforth, we regard information in both papers by citing Rey (2013). With respect to monetary policy independence, Rey says that "whenever capital is freely mobile, the global financial cycle constrains national monetary policies regardless of the exchange rate regime."

${ }^{3}$ He shows, for instance, that EMEs corporate bonds emissions doubled between 2008 and 2013. Banking flows, on the other hand, have lost their important role due to factors as the banking crisis, or the zero lower bound. A detailed discussion of the change in capital flow composition with stylized facts can be found in Section 2.
} 
In this paper, we contribute to the literature on global financial cycles and investigate empirically whether U.S. unconventional monetary policy between 2008 and 2014 is related to financial conditions in EMEs, and, whether it is transmitted through portfolio flows. ${ }^{4}$ In particular, we follow the arguments presented in the literature and analyze the following three consecutive hypotheses. First, is U.S. UMP related to portfolio (bond and equity) flows into EMEs? Second, does U.S. UMP affect financial conditions in EMEs through portfolio flows? Third, does U.S. UMP influence the conduct of monetary policy in EMEs through this channel? For our empirical analysis, we set up a structural global vector autoregressive (GVAR) model that takes country inter-linkages between the EMEs into account and allows for a structural identification of a U.S. UMP shock. We assess the magnitude of the U.S. spillovers on EMEs as a whole, on different country groups, and on individual countries.

Our main results are the following. We find that a U.S. UMP shock related to large scale asset purchases significantly increases portfolio outflows from the U.S. for almost two quarters. In the EMEs this is, on average, associated with a rise in portfolio inflows. The rise in inflows is accompanied by an increase in real output growth, equity returns, an appreciation of the real effective exchange rate, and it also affects other indicators of financial conditions. Hence, we find evidence indicating that U.S. UMP drives financial conditions in EMEs after the global financial crisis. Moreover, the results indicate that international portfolio flows are an important channel of transmission. With regard to domestic monetary policy, we find that, on average, EMEs reacted with an easing of their policy stance in response to the U.S. shock. This finding is independent of the exchange rate regime, hence, in line with a "dilemma" instead of a "trilemma" hypothesis. Concerning different country groups, we find that Asia and Latin America's financial conditions react similarly strong to the UMP shock. In both cases capital inflows increase, which is followed by real appreciation of the currency, higher equity returns and lower interest rates. The results for emerging Europe, on the other hand, are qualitatively similar, but show smaller effects due to lower capital inflows.

Aside from the literature on the global financial cycle, our work is related to three lines of empirical studies. First, it is connected to studies that investigate the effect of the Fed's UMP on EMEs (financial) conditions in event studies or similar frameworks (Aizenman et al., 2014, Eichengreen and Gupta, 2014, Bowman et al., 2015). For example, Bowman et al. (2015) investigate the response of sovereign bond yields, foreign exchange rates, and stock prices in 17 EMEs to U.S. UMP. Using a quasi event study approach with daily data, they find an effect of U.S. UMP for many countries, in particular on sovereign bond yields. We add to these studies by investing the role of capital flows as an important transmission channel of U.S. UMP. More importantly, we use an empirical model that allows for interactions between financial and real variables both within and between countries. In additional, our approach allows assessing the persistence of U.S. UMP shocks on financial conditions in EMEs on a monthly frequency.

\footnotetext{
${ }^{4}$ Henceforth we will use the terms "capital flows" and "portfolio flows" interchangeably.
} 
Second, our work is linked to papers that analyze the determinants of capital flows to EMEs (see, among others, Fratzscher, 2012, or, Forbes and Warnock, 2012). More closely, it relates to the studies that analyze the impact of the Fed's UMP on international capital flows. One set of studies analyzes this question with panel techniques (Moore et al., 2013, Lo Duca et al., 2014, Koepke, 2014, Lim et al., 2014, Ahmed and Zlate, 2014). Other studies use high frequency frameworks and event study approaches (International Monetary Fund, 2013, Fratzscher et al., 2013, Rai and Suchanek, 2014), or VAR models with aggregated capital flows (Tillmann, 2014, Dahlhaus and Vasishtha, 2014). Exemplarily, Fratzscher et al. (2013) examine the impact of QE in the U.S. on several advanced economies (AEs) and EMEs. Using high frequency data on bond and portfolio flows they show how unconventional monetary policy has contributed to portfolio reallocation as well as a re-pricing of risk in global financial markets. We complement these studies by assessing the persistence of UMP shocks on bond and equity flows in a framework that allows for structural identification of a policy shock. More importantly, we study the dynamic consequences of the induced capital flows for EMEs financial conditions in a comprehensive model that takes country interlinkages into account.

Third, our research is related to studies which analyze the effect of (U.S. conventional) monetary policy in a GVAR framework (see, for instance, Chen et al., 2015, Georgiadis, 2015a, or, Georgiadis, 2015b). Of those, Chen et al. (2015) also study spillovers from U.S. UMP on a number of variables in several AEs and EMEs. To identify the U.S. policy stance, they use a set of indicators like the U.S. corporate spread or the U.S. term spread. We differ from their approach by directly using an unconventional policy instrument, namely the Fed balance sheet, to separate exogenous policy changes from endogenous reactions to financial shocks through sign restrictions. In addition, we provide results for a broad set of EME financial indicators. Most importantly, we complement their results by highlighting the role of portfolio flows as an important channel of transmission of U.S. monetary policy.

The remainder of the paper is structured as follows. In Section 2, we review stylized facts on the importance of bond and equity flows after 2008, outline transmission channels through which U.S. UMP can affect international portfolio flows and briefly discuss the hypotheses for our empirical analysis. We then describe the data, the GVAR model and the specifications in Section 3. In Section 4, we present our main results, followed by a sensitivity analysis in Section 5. Section 6 concludes.

\section{Stylized facts, theoretical channels, and hypotheses}

In this section, we first briefly review narrative evidence on the importance of portfolio flows as a potential channel of transmission of U.S. policy conditions to EMEs after the financial crisis. We next discuss theoretical channels through which UMP in the U.S. can affect international portfolio flows. We then outline three hypotheses regarding the importance of U.S. UMP for the global financial cycle, along which we interpret our results. 


\subsection{Stylized facts: phases of "global liquidity"}

Bruno and Shin (2015a) and Rey (2013) present evidence that, before the financial crisis, international banking flows were an important transmission channel of U.S. monetary policy to EMEs and, hence, and important component of the global financial cycle. ${ }^{5}$ In this regard, Shin (2013) refers to the period from the mid 1990s until the financial crisis as the first phase of "global liquidity", which he defines as a global factor associated with financial conditions.

With the unfolding of the global financial crisis and the European debt crisis, however, Shin argues that a second phase of global liquidity sets in. In this second phase, banking flows have lost their importance. Instead, direct portfolio (bond and equity) flows now play an important role in capital flows to EMEs. One reason is that many of the global banks were European banks that had to deleverage strongly in the course of the financial crisis and the European debt crisis. Another reason is associated with many interest rates in AEs hitting the zero lower bound. With zero interest rates on many AE assets, a "search-for-yield" led to a steep increase in bond and equity issuance from EMEs borrowers previously shunned by markets as being too risky or marginal. Lastly, the nature of asset purchase policies of central banks in AEs itself may have directly contributed to increasing portfolio flows to EMEs (see Section 2.2).

Shin provides a number of stylized facts to corroborate his reasoning on the different phases. For instance, the amount of international debt securities outstanding by non-financial corporations in emerging market and developing economies almost doubled between 2008 and 2013. At the same time, international securities have almost completely replaced the formerly dominating banking loans in net external financing of EMEs. ${ }^{6}$ In accordance with the stylized facts, Bruno and Shin (2015a) find that the empirical relation between U.S. monetary policy and international banking flows is no longer present in the period after 2007.

As we are interested in the role of U.S. UMP in driving the global financial cycle and, hence, in the second phase of global liquidity, we study the role of portfolio flows to EMEs as a transmission channel of U.S. conditions. In our empirical analysis, we do not additionally include banking flows for two reasons. First, the reviewed stylized facts strongly indicate that the importance of banking flows has diminished since the beginning of the global financial crisis. Second, banking flows are available only at a quarterly frequency. Given the short time period covering the financial crisis and UMP, we do not have enough quarterly observations for a meaningful estimation of their role in the second phase of global liquidity.

\footnotetext{
${ }^{5}$ In a related theoretical paper, Bruno and Shin (2015b) provide a theoretical underpinning for this link: U.S. monetary policy affects both funding costs and leverage of global banks. These global banks then interact with local banks which, in turn, provide domestic credit and influence financial condition in EMEs.

${ }^{6}$ The stylized facts are depicted in two figures from Shin (2013), reproduced in Appendix B (see Figures 19 and 20).
} 


\subsection{How UMP can affect international portfolio flows}

From a theoretical perspective, there are several channels through which the Fed's UMP can affect portfolio allocation decisions by asset managers with a global reach and hence, international portfolio flows. In this section, we briefly review the most important theoretical mechanisms as outlined e.g. by Fratzscher et al. (2013). In principle, they are all linked to the potential domestic transmission channels of UMP brought forward by the literature (for a review, see Joyce et al., 2012).

First and foremost, a portfolio balance channel is often emphasized. A Fed purchase of e.g. U.S. Treasury bills crowds out private investment from this market segment. In turn, investors rebalance their portfolio and move to close substitute assets. Ultimately, a chain of rebalancing is set in motion which may affect the allocation of assets across countries. Second, the UMP measures can affect the risk appetite of investors, often termed "confidence or risk-taking" channel. While theoretical descriptions of this channel are often rather informal, Bekaert et al. (2013) provide empirical evidence that conventional monetary policy in the U.S. significantly impacts on financial market risk taking. An increased risk appetite might drive investors into more risky high-yield EME assets. Third, UMP might work through a signaling channel. If the Fed's measures are understood by markets as keeping future policy rates low for a period longer than previously expected, this can affect asset prices by lowering the risk-neutral price component of (future) interest rates. This induced fall in yields on securities in the U.S. can, in turn, lead to an increase in capital flows to EMEs due to a "search-for-yield". 7

Foreshadowing our UMP shock identification strategy (see Section 3.3), our approach is linked more closely to transmission channels which imply effects not only from the policy announcement, but also from the actual policy implementation. This feature is particularly relevant for the portfolio balance channel, where the available supply of assets is changed through actual purchases. Regarding the other channels, the consideration of actual purchases is often criticised as an incomplete view on the effects of UMP. This objection claims that, since amount and timing of the Fed's LSAP programs were transparently communicated, efficient markets should have fully processed the information when it was announced. However, as Fratzscher et al. (2013) argue, there are two important points against this notion. First, many UMP measures where installed precisely because markets were not functioning. Hence, mere announcements may have been less important than actual purchases because the latter ones restored liquidity and allowed investors to adjust their exposure. Second, even if market expectations were

\footnotetext{
${ }^{7}$ It has to be emphasized that these channels are not mutually exclusive and may rather be at work simultaneously (see Fratzscher et al., 2013). To disentangle them empirically is beyond the scope of this paper. Moreover, all of them imply to some extent falling yields in the U.S. and subsequent capital outflows related to a search for yields and an increase in risk appetite. The signaling channel, however, potentially also allows for a negative effect of UMP on capital flows. If new UMP measures are understood as indicating that economic conditions are worse than expected, this might induce a flight to safety and a decrease in capital outflows to EMEs as these countries are perceived as being risky. Hence, in our empirical implementation, we do not impose a sign restriction on the effect of UMP on U.S. bond and equity outflows.
} 
fairly precise about the actual amount and timing of the purchases, still the expectations about effectiveness of the actual UMP measures might not have been accurate. In their empirical analysis, Fratzscher et al. (2013) find evidence in favor of this line of reasoning. Their results show that Fed operations, such as purchases of Treasuries, had larger effects on the portfolio decisions than Fed announcements of these programs.

\subsection{Hypotheses for the empirical analysis}

Based on the discussion on the global financial cycle outlined in the introduction and arguments given in Sections 2.1. and 2.2, we summarize our research questions in three hypotheses. We will interpret our estimation results regarding the spillovers of U.S. UMP on EMEs along these hypotheses in order to draw clear implications from our estimations.

The first hypothesis relates to the role of U.S. UMP in affecting international capital flows since the beginning of the global financial crisis. In particular, it builds on the arguments brought forward by Shin (2013) that stress the importance of portfolio flows to EMEs during this particular period.

Hypothesis 1: U.S. UMP affects portfolio outflows from the U.S. and, in turn, portfolio inflows into EMEs.

If Hypothesis 1 holds true, our estimated model should show an increase in portfolio outflows from the U.S. and in portfolio inflows to EMEs after an expansionary UMP shock.

The second hypothesis links the first hypothesis to the debate on how U.S. monetary policy is an important determinant of the global financial cycle.

Hypothesis 2: U.S. UMP - through portfolio flows - drives financial conditions in EMEs.

This hypothesis is supported by our results if we find that variables which reflect financial conditions in EMEs significantly react in response to a U.S. UMP shock. For instance, equity returns should increase and/or lending rates should decrease in response to an expansionary shock. Moreover, portfolio flows should constitute an important channel of transmission of U.S. UMP to EMEs financial condition in the empirical specification, and, estimation results should not solely be driven by other potential transmission channels (e.g., global output growth).

Finally, the third hypothesis connects our estimations to the discussion on the independence of monetary policy given the strong international linkages in the globalized financial world, the "trilemma" vs. "dilemma" debate initiated by Rey (2013).

Hypothesis 3: U.S. UMP - through portfolio flows - has a significant impact on EMEs' monetary policy.

To test this last hypothesis, we split our sample into two groups of countries. The first group contains countries which peg their currency, while the second group comprises "free floaters". Evidence in favor of Hypothesis 3 is found if domestic monetary policy in both groups reacts with an expansion after an expansionary UMP shock. In contrast, if domestic monetary policy 
reacts only in countries which fix their exchange rate, but not for floaters, this would point towards the classic trilemma. ${ }^{8}$

The hypotheses are logically ordered. For the second hypothesis to be true, the first has to hold. Therefore, we first look at the effect of UMP shocks on portfolio flows from the U.S. to EMEs. Then, we turn to Hypothesis 2 and consider whether the induced portfolio flows are related to financial conditions in EMEs. If this is the case, monetary policy makers in EMEs might react to U.S. UMP shocks. Hence, we test the third hypothesis last, and only if we find evidence in favor of the first two.

\section{Data \& Empirical Methodology}

In the following section, we first outline the data we use, in particular on cross-border portfolio asset flows from the U.S., as well as the countries we consider. Then, we briefly describe the GVAR model and discuss our model specifications and UMP shock identification strategy.

\subsection{Data}

We use monthly data on U.S. portfolio outflows and EMEs financial and real conditions from $2008 \mathrm{~m} 01$ to $2014 \mathrm{~m} 12$. The sample captures the period in which the Fed conducted measures of unconventional monetary policy. The fed funds rate as a measure of conventional monetary policy, on the other hand, is at the zero lower bound for most of the sample and therefore not included in the model.

Our source of bond and equity flows are the monthly estimates of changes in U.S. holdings of foreign securities provided by the Federal Reserve Board. The dataset is based on estimations that combine two different types of data reported by the Treasury International Capital Reporting System (TIC). On the one hand, data is based on annual benchmark surveys of U.S. holdings of foreign securities. On the other hand, transaction data from mandatory monthly TIC surveys, filed by U.S. banks, securities dealers, and other entities that report net purchases of foreign assets by U.S. residents, is used. Bertaut and Tryon (2007) for the period 2007-2010 and Bertaut and Judson (2014) for the period 2011-2014 combine the monthly transaction data with the yearly survey data to obtain estimates on monthly levels for both flows and valuation changes. ${ }^{9}$ The dataset covers portfolio investment in long-term securities, specifically debt instruments with greater-than-one-year original maturity (i.e. bonds), and equities. It is widely used in

\footnotetext{
${ }^{8}$ Note that for this reasoning to hold, all sample countries have to have an open capital account. Based on the usual classifications, this holds true for our entire sample of countries. Over time and in response to the crisis, however, some countries experimented with different forms of limited capital controls. A detailed analysis of their effects is beyond the scope of the paper, but an interesting question for future research.

${ }^{9}$ The data can be accessed at the following website: http://www.federalreserve.gov/pubs/ifdp/2014/1113/default.htm. The estimated monthly flows are subject to several adjustments to reduce the noise and biases in the underlying monthly TIC flow data. The necessary steps are in detail described in Bertaut and Tryon (2007) and Bertaut and Judson (2014).
} 
the literature to study foreign portfolio flows into U.S. securities and U.S. flows into foreign securities and considered as highly accurate (see, for instance, Curcuru et al., 2010, or Hanlon et al., 2015).

Such a large and comprehensive dataset on bilateral capital flows is available only for flows out of the U.S. For the purpose of our analysis, however, this is not an issue as we are interested in the effects of U.S. monetary policy that should affect flows from the U.S. more heavily than bilateral flows involving only other countries. Moreover, U.S. portfolio flows are of major relevance for the emerging market economies that we study. According to data from the 2012 Coordinated Portfolio Investment Survey, U.S. investors account for more than a third of all crossborder investment in bonds and equities of emerging market economies (see Bertaut and Judson, 2014). With regard to the receiving countries, bond and equity investment are an important component of all foreign investments in EMEs. For instance, Shin (2013) and Turner (2014), based on BIS data, indicate that in EMEs non-financial corporations' international securities borrowing increased from 200 billion USD in late 2008 to 450 billion USD by the beginning of 2013.

Further data on EMEs real and financial conditions is obtained from Thomson Reuters Datastream and the IMF's International Financial Statistics (IFS) database while data on U.S. real gross domestic product (GDP), consumer price index (CPI), the Fed Balance Sheet and the volatility index VIX is taken from the Federal Reserve Bank of St. Louis database. ${ }^{10}$ All variables in nominal terms have been converted to real terms prior to the estimation. A detailed description of variable definitions and transformations can be found in Appendix A.

Selection of countries into the sample is driven by different considerations. First, we do not include countries that have limited access to global financial markets and hardly issue securities and equities globally. Second, we only add countries that have comprehensive monthly data on economic and financial conditions available. Third, we exclude China as it plays a distinct role through its trade and financial linkages to the U.S. and its particular institutional settings. Nevertheless, the dataset covers a broad range of EMEs and closely resembles the sample of many studies on emerging markets (see, for instance, Bowman et al., 2015 and Aizenman et al., 2014). Ultimately, our sample of EMEs contains the following countries: Argentina, Brazil, Chile, Colombia, Hungary, India, Indonesia, Israel, Korea, Mexico, Malaysia, Peru, the Philippines, Poland, Russia, Singapore, South Africa, Thailand, and Turkey.

\footnotetext{
${ }^{10}$ Time series with monthly observations for real GDP are constructed by interpolating the quarterly figures with a monthly index of industrial production, using the method of Chow and Lin (1971). Data for industrial production is taken from the same source as the data for GDP. An exception is Singapore, where an index of industrial production is obtained from the monetary authority of Singapore. A lending rate for Turkey is obtained from the central bank of Turkey.
} 


\subsection{The GVAR model}

To analyze the effects of U.S. UMP on a broad set of EMEs while taking all potential crosscountry interlinkages into account, in principle, a large scale vector autoregressive (VAR) model of the following form would be adequate:

$$
\boldsymbol{y}_{t}=\boldsymbol{\mu}+\boldsymbol{\lambda} t+\boldsymbol{\Gamma}_{1} \boldsymbol{y}_{t-1}+\boldsymbol{\Gamma}_{2} \boldsymbol{y}_{t-2}+\ldots+\boldsymbol{\Gamma}_{p} \boldsymbol{y}_{t-p}+\boldsymbol{\nu}_{t}
$$

where $\boldsymbol{y}_{t}=\left(\begin{array}{llll}\boldsymbol{y}_{1 t}^{\prime} & \boldsymbol{y}_{2 t}^{\prime} & \ldots & \boldsymbol{y}_{N t}^{\prime}\end{array}\right)^{\prime}$ denotes the vector of $k$ endogenous variables stacked across $N$ countries for $t=1,2, \ldots, T$ time periods, $\boldsymbol{\Gamma}_{s}, s=1,2, \ldots, p$ denotes an $(N k \times N k)$ matrix of coefficients, $\boldsymbol{\mu}$ and $\boldsymbol{\lambda}$ denote $N k \times 1$ vectors of constant and trend coefficients, and $\boldsymbol{\nu}_{t}=$ $\left(\boldsymbol{\nu}_{1 t}^{\prime} \boldsymbol{\nu}_{2 t}^{\prime} \ldots \boldsymbol{\nu}_{N t}^{\prime}\right)^{\prime}$ represents shocks. While the model can accommodate a rich structure of cross-country interrelations, estimation of this model under a fully flexible parametrization is not feasible due to the large number of parameters, even for moderate sizes of $N$.

Dees et al. (2007) employ a parsimonious way of re-specifying this model by modeling the relations between countries via their bilateral trade linkages (the "global VAR" (GVAR) approach). The GVAR is, in principle, a set of linked country VAR models with exogenous regressors (VARX) for each country $i=1,2, \ldots, N$

$$
\boldsymbol{y}_{i t}=\sum_{s=1}^{p} \boldsymbol{A}_{i s} \boldsymbol{y}_{i t-s}+\sum_{s=0}^{p} \boldsymbol{B}_{i s} \boldsymbol{y}_{i t-s}^{*}+\sum_{s=0}^{p} \boldsymbol{C}_{i s} \boldsymbol{d}_{t-s}+\lambda_{i} t+\boldsymbol{\mu}_{i}+\boldsymbol{\varepsilon}_{i t},
$$

where $\boldsymbol{y}_{i t}$ is a vector of $k_{i}$ endogenous variables and $\boldsymbol{y}_{i t}^{*}$ is a vector of $k_{i}^{*}$ country-specific (weakly exogenous) "foreign variables". In order to take account of potential observed common factors (in addition to unobserved common factors captured by the foreign variables), the models include the $k_{d}$-dimensional vector $\boldsymbol{d}_{t}$ of "global" variables affecting every country. ${ }^{11}$ The coefficient matrices $\boldsymbol{A}_{i s}, \boldsymbol{B}_{i s}$ and $\boldsymbol{C}_{i s}, s=0,1,2, \ldots, p$, as well as the coefficient vectors $\boldsymbol{\lambda}_{i}$ and $\boldsymbol{\mu}_{i}$ are of suitable dimension.

The key feature of this approach is to define the so-called foreign variables, $\boldsymbol{y}_{i t}^{*}$, as weighted averages of other countries' variables with bilateral weights $w_{i j}$ :

$$
\boldsymbol{y}_{i t}^{*}=\sum_{j=1}^{N} w_{i j} \boldsymbol{y}_{j t}, \quad \sum_{j=1}^{N} w_{i j}=1, \quad w_{i j} \geq 0 \forall i, j, \quad w_{i i}=0 .
$$

The weights capture the exposure of country $i$ to country $j$ based on trade linkages. The foreign variables $\boldsymbol{y}_{i t}^{*}$ are assumed to be weakly exogenous with respect to the parameters of the VARX model in Equation (2).

\footnotetext{
${ }^{11}$ Note that the common lag order is presented for convenience of processing of the coefficient matrices and does not imply a restriction to the estimation of the model since the coefficient matrices can be padded with zeros after country-wise estimation.
} 
Summarizing the influence of global variables and deterministics in the vector $\boldsymbol{h}_{i t}=$ $\sum_{s=0}^{p} \boldsymbol{C}_{i s} \boldsymbol{d}_{t-s}+\boldsymbol{\lambda}_{i} t+\boldsymbol{\mu}_{i}$ for notational simplicity, Equation (2) can be rewritten as

$$
\boldsymbol{\Phi}_{i 0} \boldsymbol{z}_{i t}=\sum_{s=1}^{p} \boldsymbol{\Phi}_{i s} \boldsymbol{z}_{i t-s}+\boldsymbol{h}_{i t}+\boldsymbol{\varepsilon}_{i t}
$$

where $\boldsymbol{z}_{i t}=\left(\boldsymbol{y}_{i t}^{\prime}, \boldsymbol{y}_{i t}^{\prime *}\right)^{\prime}, \boldsymbol{\Phi}_{i 0}=\left(\boldsymbol{I}_{k},-\boldsymbol{B}_{i 0}\right)$, and $\boldsymbol{\Phi}_{i s}=\left(\boldsymbol{A}_{i s},-\boldsymbol{B}_{i s}\right)$. Hence, $\boldsymbol{z}_{i t}$ is linked to the endogenous variables $\boldsymbol{y}_{t}=\left(\boldsymbol{y}_{1 t}^{\prime} \boldsymbol{y}_{2 t}^{\prime} \ldots \boldsymbol{y}_{N t}^{\prime}\right)^{\prime}$ through the link matrix $\boldsymbol{W}_{i}$ in the following way

$$
\boldsymbol{z}_{i t}=\boldsymbol{W}_{i} \boldsymbol{y}_{i t}, \quad \boldsymbol{W}_{i}=\left(\begin{array}{ccccc}
\mathbf{0} & \ldots & \boldsymbol{I}_{k} & \ldots & \mathbf{0} \\
w_{i 1} \boldsymbol{I}_{k} & \ldots & w_{i i} \boldsymbol{I}_{k} & \ldots & w_{i N} \boldsymbol{I}_{k}
\end{array}\right)
$$

Using this relation, Equation (4) is equivalent to

$$
\boldsymbol{\Phi}_{i 0} \boldsymbol{W}_{i} \boldsymbol{y}_{t}=\sum_{s=1}^{p} \boldsymbol{\Phi}_{i s} \boldsymbol{W}_{i} \boldsymbol{y}_{t-s}+\boldsymbol{h}_{i t}+\boldsymbol{\varepsilon}_{i t}
$$

Stacking the individual country VARX models yields the following equation ${ }^{12}$ for $y_{t}$

$$
\boldsymbol{G}_{0} \boldsymbol{y}_{t}=\sum_{s=1}^{p} \boldsymbol{G}_{s} \boldsymbol{y}_{t-s}+\boldsymbol{h}_{t}+\varepsilon_{t}
$$

which has to be pre-multiplied by $\boldsymbol{G}_{0}^{-1}$ to obtain the autoregressive representation of the GVAR model, the so-called global solution,

$$
\boldsymbol{y}_{t}=\sum_{s=1}^{p} \boldsymbol{F}_{s} \boldsymbol{y}_{t-s}+\tilde{\boldsymbol{h}}_{t}+\boldsymbol{u}_{t}
$$

with $\boldsymbol{F}_{j}=\boldsymbol{G}_{0}^{-1} \boldsymbol{G}_{j}, \tilde{\boldsymbol{h}}_{t}=\boldsymbol{G}_{0}^{-1} \boldsymbol{h}_{t}$ and $\boldsymbol{u}_{t}=\boldsymbol{G}_{0}^{-1} \varepsilon_{t}$. Estimates for the parameters of the global solution can be constructed based on the estimated individual-country VARX models. The global solution is equivalent to the reduced-form VAR representation of Equation (1), but with numerous within- and cross-equation restrictions. It can thus be used to perform standard VAR analysis and obtain structural impulse response functions (IRFs), as we do.

\subsection{Model specifications}

In specifying the underlying VARX models for the individual countries, we treat the U.S. equation differently than the EME equations. We include a different set of weakly exogenous variables for the U.S., similar to what is commonly done in GVAR applications, due to the dominant role

$$
{ }^{12} \text { where } \boldsymbol{G}_{0}=\left(\begin{array}{c}
\boldsymbol{\Phi}_{10} \boldsymbol{W}_{1} \\
\boldsymbol{\Phi}_{20} \boldsymbol{W}_{2} \\
\ldots \\
\boldsymbol{\Phi}_{N 0} \boldsymbol{W}_{N}
\end{array}\right), \boldsymbol{G}_{s}=\left(\begin{array}{c}
\boldsymbol{\Phi}_{1 s} \boldsymbol{W}_{1} \\
\boldsymbol{\Phi}_{2 s} \boldsymbol{W}_{2} \\
\ldots \\
\boldsymbol{\Phi}_{N s} \boldsymbol{W}_{N}
\end{array}\right), \boldsymbol{h}_{t}=\left(\begin{array}{c}
\boldsymbol{h}_{1 t} \\
\boldsymbol{h}_{2 t} \\
\ldots \\
\boldsymbol{h}_{N t}
\end{array}\right) \text { and } \varepsilon_{t}=\left(\begin{array}{c}
\varepsilon_{1 t} \\
\varepsilon_{2 t} \\
\ldots \\
\varepsilon_{N t}
\end{array}\right) \sim \operatorname{iid}\left(0, \boldsymbol{\Sigma}_{\varepsilon}\right) \text {. }
$$


of the U.S. in global financial markets (see, for instance, Eickmeier and $\mathrm{Ng}, 2015$, Georgiadis, 2015a, or Chen et al., 2015). In particular, we are interested in a UMP shock from the U.S. and thus have to build an U.S. model that allows for an identification of such a shock.

For the U.S., we set up a VARX model which resembles VARs from the literature that analyze conventional monetary policy and contain output, inflation, and the Fed funds rate (see, among many others, Christiano et al., 1999). However, to account for the zero lower bound and UMP, the Fed funds rate is replaced by the Fed balance sheet as the monetary policy instrument as in Gambacorta et al. (2014). In addition, the VIX is added to the model to account for financial market uncertainty and to identify an exogenous innovation in the balance sheet (see Section 3.4). Lastly, we add total U.S. portfolio outflows as a variable of interest for our research question. In sum, the U.S. model takes the following form: ${ }^{13}$

$$
\begin{aligned}
& \boldsymbol{y}_{U S, t}=(\text { output }, \text { inflation, VIX, Fed balance sheet }, \text { bond outflows })^{\prime}, \\
& \boldsymbol{y}_{U S, t}^{*}=(\text { foreign output, foreign inflation })^{\prime} .
\end{aligned}
$$

The VARX specification for the EMEs is restricted by the rather short period of U.S. UMP. Given the limited number of observations, we cannot include all variables of interest into one large model. Instead, we consider different models that vary with regard to the specification of the endogenous variables in the VARX models. First, we estimate one model that measures the response of real economic conditions in the EMEs to a U.S. UMP shock (business cycle (BC) model):

$$
\begin{aligned}
& \boldsymbol{y}_{i t}=(\text { output }, \text { bond inflows, real interest rate })^{\prime}, \\
& \boldsymbol{y}_{i t}^{*}=(\text { U.S. bond outflows })
\end{aligned}
$$

In a second step, we estimate several small models to capture the effect of a U.S. UMP shock on financial conditions in EMEs (financial conditions (FC) models I - III). Each model includes a subset ot the relevant financial variables:

FC I: $\quad \boldsymbol{y}_{i t}=(\text { bond inflows, real exchange rate, real interest rate })^{\prime}$, $\boldsymbol{y}_{i t}^{*}=($ U.S. bond outflows);

FC II: $\quad \boldsymbol{y}_{i t}=(\text { bond inflows, real interest rate, equity returns })^{\prime}$, $\boldsymbol{y}_{i t}^{*}=($ U.S. bond outflows);

FC III: $\quad \boldsymbol{y}_{i t}=(\text { bond inflows, equity returns, real lending rate })^{\prime}$, $\boldsymbol{y}_{i t}^{*}=$ (U.S. bond outflows).

\footnotetext{
${ }^{13}$ All models for the U.S. and for the EMEs include a constant an a linear time trend.
} 
All models share the same VARX model for the U.S. to ensure that the UMP shock is the same across models. Moreover, all models include U.S. total portfolio outflows as a foreign variable and, hence, as a channel of shock transmission from the U.S. In our baseline specification, U.S. portfolio flows are the only foreign variable in the EME VARX models. As a robustness check, however, we later estimate models with additional foreign variables for EMEs. For instance, we include foreign output (in all the models), and U.S. equity returns or the foreign real interest rate (in the models for financial conditions) as transmission channels. This also aims at ensuring that the shock transmission is not solely driven by real or financial conditions in the U.S. via trade or financial linkages, but by portfolio flows. Additional robustness exercises are including commodity price inflation as an exogenous (global) variable and estimating a larger model for financial conditions that contains equity returns, the exchange rate, capital inflows and the interest or lending rate, respectively. Lastly, for a broader picture of how U.S. UMP affects financial conditions in EMEs, we also estimate models that include foreign reserve accumulation and long term government bond yields. Following Georgiadis (2015b), we include the variables, with the exception of the VIX, the Fed's balance sheet and the interest rates, in all models in first differences of their logarithms. ${ }^{14}$

\subsection{UMP shock identification}

To identify an UMP shock, we follow the approach of Gambacorta et al. (2014) that allows us to distinguish between an exogenous innovation to the Fed balance sheet (UMP shock) and an endogenous reaction of the central bank to the state of the economy. This is done by imposing a mixture of zero and sign restrictions on the structural impulse response functions.

First, we assume that a shock to the Fed balance sheet, the policy instrument, only has a lagged impact on output growth and inflation. In the other direction, the Fed reacts instantaneously to innovations to output and inflation as commonly assumed in VAR analysis of monetary policy transmission (see, among many others, Christiano et al., 1999). ${ }^{15}$

Second, we use the VIX to disentangle exogenous innovations to the central bank balance sheet from the endogenous response to financial turmoil. To that aim, we use the sign restrictions displayed in Table 1. On the one hand, we assume that an expansionary UMP shock does not increase the VIX. This reflects the notion that UMP had the effect of mitigating concerns about financial instability. It is also in line with results by Bekaert et al. (2013) who show that an expansionary conventional monetary policy shock has a lowering effect on the VIX. On the other

\footnotetext{
${ }^{14}$ This has mainly two reasons. First, using differences ensures stability of the model across all different specifications. Estimating the different models in (log) levels using co-integrated global vector error-correction models (GVECMs) often yields explosive dynamics which makes a meaningful interpretation of the results difficult. Second, given our short sample period, estimations of the long-run relationship between the variables and, hence, the co-integration rank of GVECM have to be treated with caution. Therefore, for our application using a GVECM does not provide insurance against model mis-specification.

${ }^{15}$ Similarly, we assume that the VIX, as a financial variable, reacts instantaneously to innovations in the macro variables. On the other hand, shocks to financial market uncertainty affect output and inflation with a lag.
} 
hand, we define a shock that increases both the VIX and the Fed balance sheet as a financial market risk shock to which the Fed responds, as in the immediate Lehman aftermath when a massive amount of mortgage-backed securities were purchased.

Table 1: Sign restrictions to identify UMP shock

\begin{tabular}{rcccc}
\hline & Output & Inflation & VIX & Fed Balance Sheet \\
\hline Unconventional Monetary Policy Shock & 0 & 0 & $\leq 0$ & $>0$ \\
Financial Market Risk Shock & 0 & 0 & $>0$ & $>0$ \\
\hline
\end{tabular}

The sign restrictions are imposed on impact and in the first month after the shock. This is done to allow for a UMP shock to primarily impact on the VIX and impact on the Fed balance sheet mainly with a lag. Hence, it can, to a certain extent, accommodate the fact that UMP measures were announced before their implementation. Nevertheless, the shock will primarily capture the actual implementation of UMP, namely the purchases of assets that enlarge the balance sheet. In this sense, it can be regarded as an overall "stock effect" of the Fed's quantitative easing (LSAP) policies. $^{16}$

To implement the sign restrictions in the GVAR, we proceed as follows. First, we estimate the GVAR and retrieve its global solution given in Equation (8) that includes all endogenous variables across all countries. We then carry out a Cholesky decomposition of the covariance matrix of the residuals of the model, $\boldsymbol{u}_{t}$, obtaining a lower triangular matrix $\boldsymbol{P}$. Multiplying this matrix with the corresponding moving-average coefficients of the global solution of the GVAR, $\boldsymbol{\Psi}_{h}, h=0,1,2, \ldots$, yields the standard orthogonalized IRF at horizon $h, \Psi_{h} \boldsymbol{P}$.

This identification scheme, however, does not yet satisfy the sign restrictions as it implies one zero in the contemporaneous relation between the VIX and the Fed balance sheet. In the next step, we multiply the preliminary IRF by an orthonormal rotation matrix $\boldsymbol{Q}(\theta)$ that takes the following form:

$$
\boldsymbol{Q}(\theta)=\left(\begin{array}{cccc}
\boldsymbol{Q}^{U S}(\theta) & 0 & \ldots & 0 \\
0 & \boldsymbol{I}_{k} & & \vdots \\
\vdots & & \ddots & \\
0 & \ldots & & \boldsymbol{I}_{k}
\end{array}\right), \quad \text { with } \boldsymbol{Q}^{U S}(\theta)=\left(\begin{array}{cccc}
\boldsymbol{I}_{2} & 0 & 0 & 0 \\
0 & \cos (\theta) & -\sin (\theta) & 0 \\
0 & \sin (\theta) & \cos (\theta) & 0 \\
0 & 0 & 0 & 1
\end{array}\right)
$$

where $\boldsymbol{I}_{m}$ is the identity matrix of dimension $m \times m$. The respective IRF is then given by $\boldsymbol{\Psi}_{h} \boldsymbol{P Q}(\theta)$. We draw rotation matrices $\boldsymbol{Q}(\theta)$ by drawing $\theta$ from a uniform distribution over the interval $[0, \pi]$ until we obtain an $\operatorname{IRF} \Psi_{h} \boldsymbol{P Q}(\theta)$ that satisfies the sign restrictions in Table 1. The UMP shock is then given by the corresponding element in $\boldsymbol{\eta}_{t}=\boldsymbol{Q}^{\prime}(\theta) \boldsymbol{P}^{-1} \boldsymbol{u}_{t}$ that raises the Fed balance sheet and, at the same time, does not increase the VIX.

\footnotetext{
${ }^{16}$ It is often argued that only the policy announcements and not the actual purchases matter for economic and financial outcomes. However, as outlined in section 2.2, there are both theoretical arguments and empirical findings that stress the importance of actual purchases.
} 
In principle, there is a variety of models with different rotation matrices $\boldsymbol{Q}(\theta)$ that satisfy the sign restriction. We account for this fact by drawing rotation matrices $\boldsymbol{Q}(\theta)$ until we obtain 1000 admissible IRFs. ${ }^{17}$ Then, we apply the "median targeting" approach by Fry and Pagan (2007) and select among admissible models the one that yields IRFs that are closest to the median response across models and horizons. The approach has the advantage that the reported final IRFs are generated by one particular model and that the shocks are orthogonal. For statistical inference, we carry out 200 bootstrap replications of the same setup, but with only one draw of the rotation matrix in each replication.

\section{Panel results}

In this section, we present our estimation results for the full panel of countries. First, we show that the identified UMP shocks align well with the policy stance of the Fed over the sample period, and present the response of U.S. variables to the UMP shock. Then, we turn to the EMEs and present average impulse response functions for each of the different models that we estimate. Lastly, we discuss further specifications and evaluate the robustness of our results. The results from this section and from the next one ${ }^{18}$ allow us to draw conclusions on Hypotheses 1 and 2.

\subsection{Time series of exogenous balance sheet innovations}

For a better interpretation of the identified U.S. UMP shocks, we first examine the time series of the identified shocks. This inspection allows us to assess whether the major policy measures taken by the Fed during and after the financial crisis are reflected in the estimated innovations. ${ }^{19}$

Figures 1 shows the cumulative time series of the identified UMP innovations in the balance sheet as well as the time series of identified financial market risk shocks. The figure provides a picture of how UMP and financial turmoil shocks relate to dates of important UMP measures (phases of QE are depicted as shaded areas). Given that most of the measures have to some extent an unexpected component, this is a useful check of the identification approach. The shock series depicted in the figure correspond to the model that yields the median IRF in the baseline model with equity prices, i.e. financial conditions model II. The shocks, however, are almost identical across different specifications of the model. The sum of the shocks is, by construction, zero over the sample period and the scale is standard deviations. A rise in the cumulative shock series reflects an expansionary balance sheet shock while a decline is associated with a tightening of the balance sheet relative to the average endogenous response to other shocks hitting the economy.

\footnotetext{
${ }^{17} \mathrm{~A}$ large number of studies reports acceptance rates for this kind of approach. In our case, it takes 1448 rotations to obtain 1000 valid draws based on the point estimates of our baseline model with equity prices. Acceptance rates for the other specifications are of similar magnitude.

${ }^{18}$ The next section presents the mean responses for three geographical regions: Latin America, Asia and Europe.

${ }^{19}$ In doing so, we follow Boeckx et al. (2014) who apply a similar identification strategy for the ECB's UMP.
} 
The figure shows that the identified balance sheet shocks capture the monetary policy stance of the Fed over the sample period well. In particular, the phases of quantitative easing are, on average, associated with expansionary UMP shocks. On the other hand, ending the respective program of QE implies a contractionary balance sheet impulse. This is in line with the notion that the first two programs were ended despite no major improvement in economic conditions and financial stability. Moreover, almost no shock is associated with "operation twist", the exchange of short-term for long-term bonds, that did not affect the Fed balance sheet.

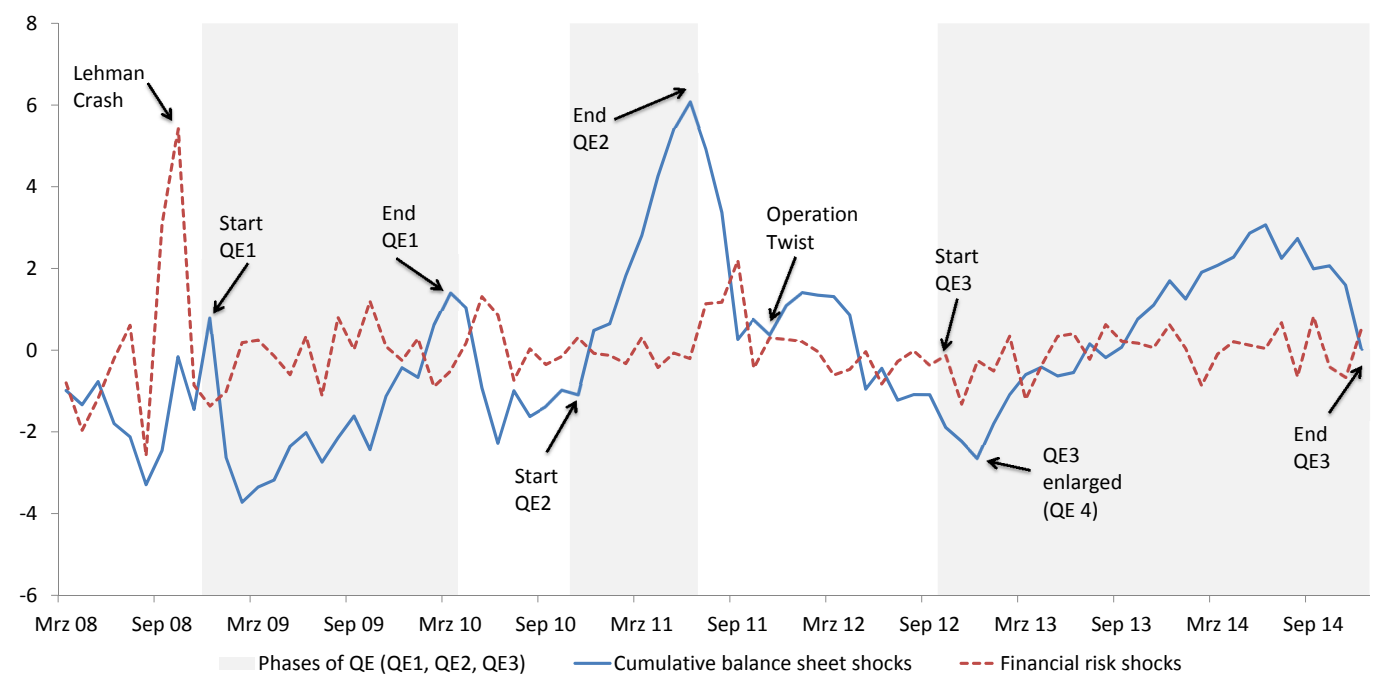

Figure 1: Time series of cumulative balance sheet shocks and financial market risk shocks

The financial market risk shock, in contrast, most notably captures the turmoil associated with the collapse of Lehman Brothers in 2008. Hence, most of the Fed balance sheet enlargement directly after Lehman is regarded by the model as an endogenous reaction to the collapse and not an exogenous policy innovation. This reflects the identification strategy which exactly aims at disentangling an endogenous reaction to financial market turmoil from expansionary policy. Summarizing, we can conclude that the identified balance sheet shocks capture the most important events and phases of UMP in the U.S. and, hence, are a good indication of the unconventional monetary policy stance for our sample period.

\subsection{U.S. reaction to UMP shock}

Next, we look at the U.S. part of the estimated GVARs to see if a UMP shock is related to an increase in capital outflows. Impulse response functions for the U.S. variables to a one standard deviation expansionary UMP shock are depicted in Figure $2 .{ }^{20}$ The standard deviation shock corresponds to an enlargement of the Fed balance sheet of roughly three percentage points (pp).

\footnotetext{
${ }^{20}$ Exemplarily, we present impulse response functions for the financial conditions model FC I. However, the reaction in the U.S. part of the model is very similar for different specifications of the EMEs.
} 
As in all the following figures, the solid line represents the median response, and the red dotted lines represent bootstrapped $16 \%$ and $84 \%$ quantiles.

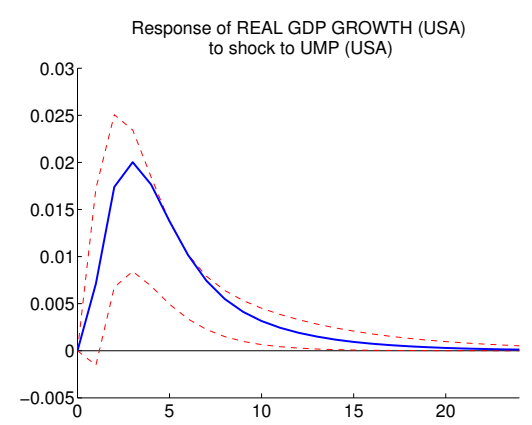

(a) real gdp growth

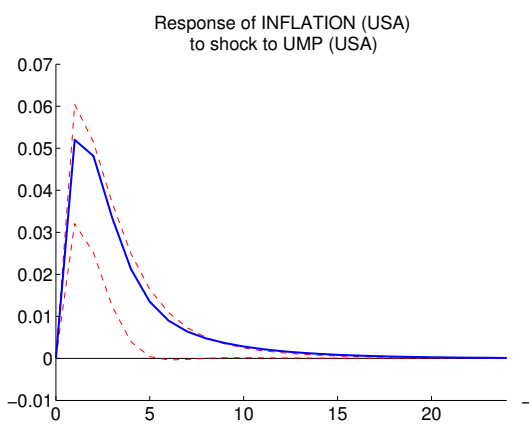

(b) inflation rate

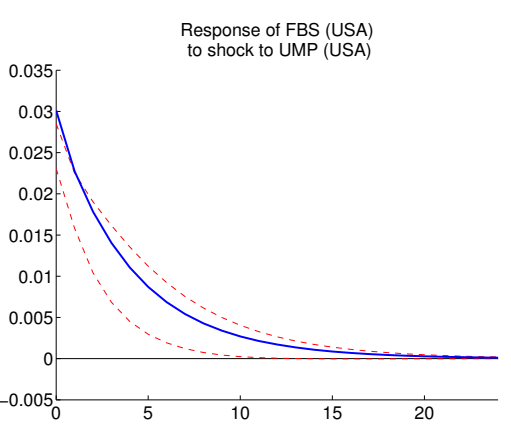

(c) fed balance sheet

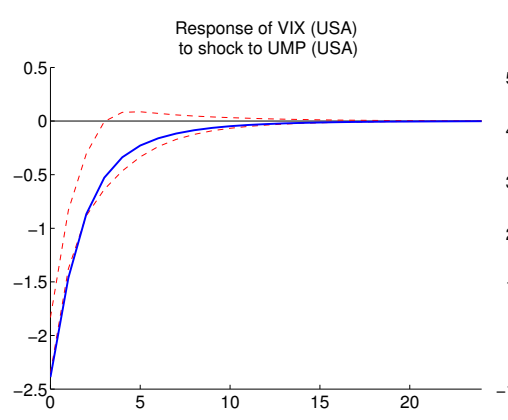

(d) vix

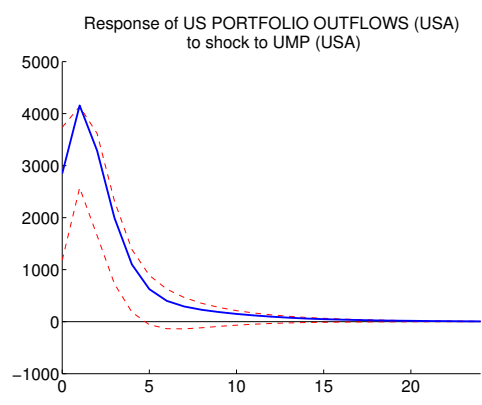

(e) portfolio outflows

Figure 2: Responses of U.S. variables to U.S. UMP shock - model: FC I

Panel (a) shows the response of monthly real GDP growth. The response is positive and significant and reaches its peak after around 4 months at an increase of $0.02 \mathrm{pp}$. The response of inflation to the UMP shock (panel $b$ ) is also significantly positive and peaks at 0.05 pp increase and remains significant for around five months. Panels (c) and (d) show the responses of the VIX and of the FED's balance sheet to the identified UMP shock. The VIX is significantly reduced for three months, and the Fed Balance Sheet is significantly increased for around 5 months. These results are qualitatively very similar to the ones obtained by Gambacorta et al. (2014) in a similar setting for the U.S. only. However, the magnitude by which GDP and inflation respond is smaller than in the U.S.-only model, which most likely reflects the larger parameter space of the GVAR.

The last panel (e) shows the IRF of U.S. capital outflows. After a UMP shock, outflows increase immediately, reaching a peak at around four billions USD after two months. This result is in line with, for instance, Fratzscher et al. (2013), who find a large immediate effect of the Fed's asset purchases on portfolio flows from and to the U.S. However, our results show that the effect does not only appear on impact. Instead, the UMP leads to a significant increase in portfolio outflows for around half a year. This finding is a first indication in favor of our Hypothesis 1: portfolio outflows significantly increase after the actual implementation of UMP in the U.S. 


\subsection{EMEs' mean response to UMP shock}

In this section we examine the average impulse responses of EMEs after the UMP shock in our three different models. First, to consider the business cycle we take a look at some real variables in EMEs. ${ }^{21}$ Then, we present the mean responses from the financial conditions models FC I - III. The results from this section (and from the next one, which groups results by regions) allow us to test Hypotheses 1 and 2.

\subsubsection{EMEs' business cycle model}

The resulting increase in capital outflows from the U.S. should be translated into an increase in capital inflows into EMEs. Figure 3 shows the mean responses of all the EMEs ${ }^{22}$ for the business cycle model, after a UMP shock in the U.S. and the subsequent increase in U.S. portfolio outflows.

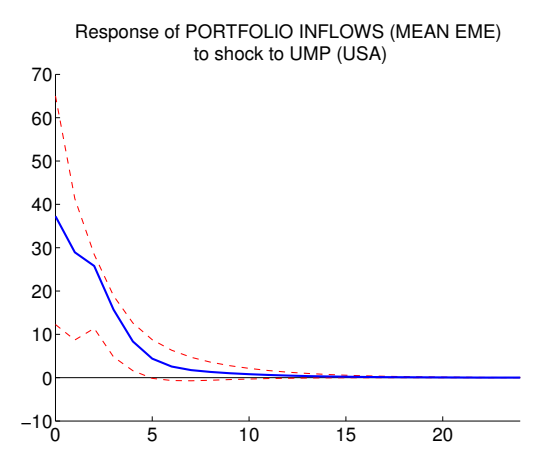

(a) portfolio inflows

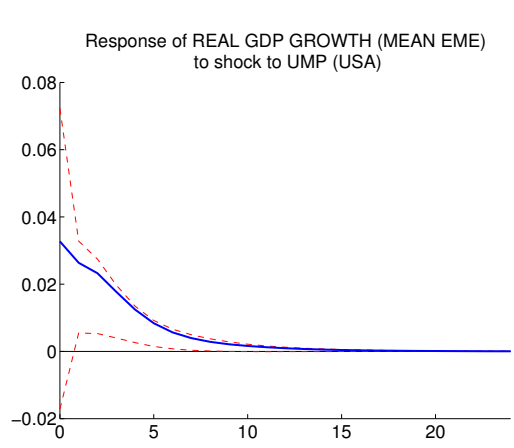

(b) real GDP growth

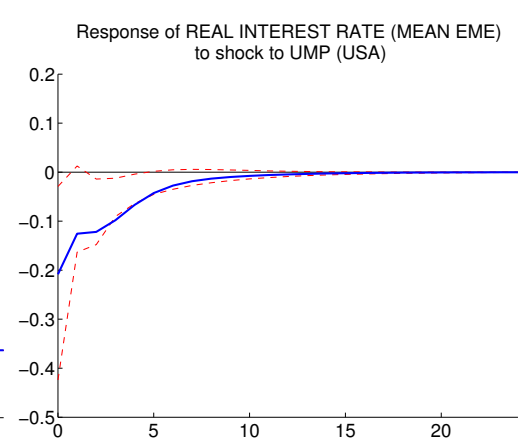

(c) real interest rate

Figure 3: Responses of EME variables (mean) to U.S. UMP shock - model: Business Cycle

Indeed, the first panel (a) of the figure shows that, on average, U.S. portfolio inflows to EMEs increase significantly after a UMP shock. However, some remarks about this results have to be made: the mean increase in inflows hast its peak at around 40 million USD, i.e. around 800 million USD are estimated to flow into EMEs after the shock. This represents only about $20 \%$ of the response of outflows from the U.S. This does not necessarily come as a surprise, since our data capture only the flows going directly from the U.S. to EMEs. The data do not capture possibly large indirect flows from the U.S. to an EME through other financial centers like the United Kingdom or Hong Kong. In this regard, we interpret our results as a lower bound of the actual portfolio inflows into EMEs after a UMP shock.

Turning to the real variables, the mean response of output in EMEs to a U.S. UMP shock is positive and significant. Real GDP growth increases by around 0.3 percentage points while the

\footnotetext{
${ }^{21}$ The mean impulse response is calculated as the mean of the IRFs across all countries.

${ }^{22}$ Except from Argentina, which is included in the estimation, but it is excluded from the calculation of the mean, since it is a large outlier. The IRF of the interest rate is - compared to all other countries - extremely high. Figures $19-23$ in the Appendix show the mean response including Argentina, and the responses for Argentina for the models BC and FC I.
} 
effect fades after over six months (see panel (b)). This suggests that U.S. UMP stimulates output in EMEs via portfolio flows. Panel (c), moreover, shows the mean response of the policy interest rate in the EMEs. The interest rate, on average, decreases in response to the shock. This indicates procyclicality of the monetary policy response as interest rates decrease while output increases. Moreover, this is a first indication that EME monetary policy is expansionary in response to expansionary U.S. policy. As this issue is central for our Hypothesis 3, we will address it more closely in the following (sub)sections.

\subsubsection{EMEs' financial conditions models}

To draw conclusion regarding our Hypotheses 1 and 2, and to analyze the assertions that U.S. monetary policy drives a global financial cycle and has implications on the exchange rate and monetary policy of other countries, we now turn to our models on EMEs financial conditions. Figure 4 shows the results of our FC I model that includes the responses of portfolio inflows, real exchange rates and real interest rates to a U.S. UMP shock.

Following the shock, portfolio inflows increase in similar magnitude as in the model for the business cycle, i.e. UMP in fact leads to an increase in portfolio inflows to EMEs. This surge in inflows is followed by a real appreciation of the exchange rate. The real exchange rate decreases by $0.6 \mathrm{pp}$, and stays significantly negative for around five months. At the same time, the mean monetary policy response suggests that monetary authorities in EMEs lower the interest rate as in the model for the business cycle, though the decrease is not significant in this case. One possible explanation is that monetary policy authorities to some extent try to deflect the inflows by lowering the interest rate, in an attempt to avoid an even larger appreciation of the exchange rate.

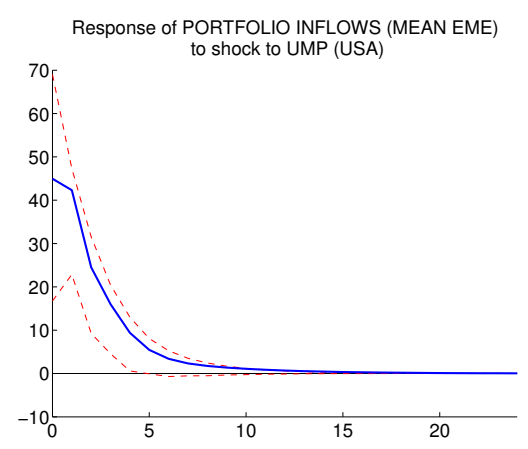

(a) portfolio inflows

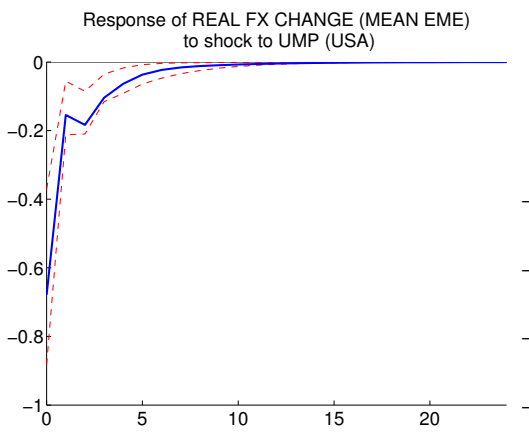

(b) real fx change

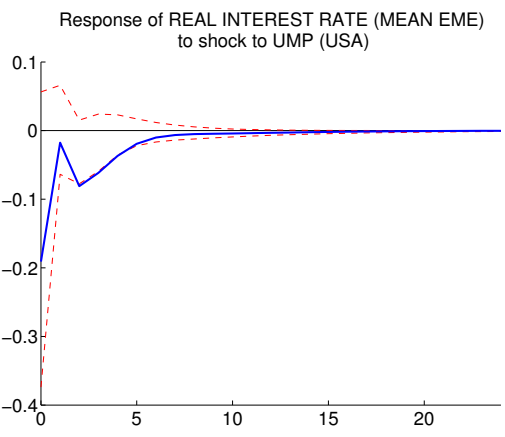

(c) real interest rate

Figure 4: Responses of EME variables (mean) to U.S. UMP shock - model: FC I

Results for the further models on financial conditions (FC II and FC III) are given in Figures 5 and 6 . The mean responses of capital inflows stay qualitatively and quantitatively the same compared to the two models discussed so far. In FC II, there is a significant decrease of $0.2 \mathrm{pp}$ (quantitatively similar as in the models discussed above) of the policy rate after the portfolio 
inflows (although even less significant). As a consequence of the inflows and the expansionary monetary policy, equity returns significantly increase by $0.4 \mathrm{pp}$.

The results for the model FC III show a significant increase of equity returns. The real lending rate, our proxy for domestic credit, significantly decreases for around six months by 0.15 pp. The IRFs of both variables suggest that financial conditions are indeed stimulated by a UMP shock in the U.S. and the subsequent capital flows. In general, our results do strongly indicate that U.S. UMP significantly affects financial condition in EMEs (Hypothesis 2).

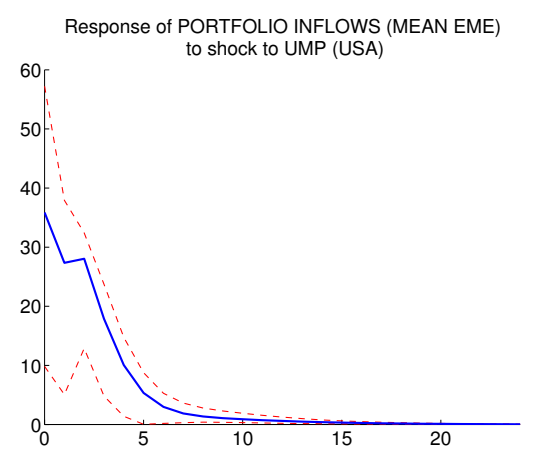

(a) portfolio inflows

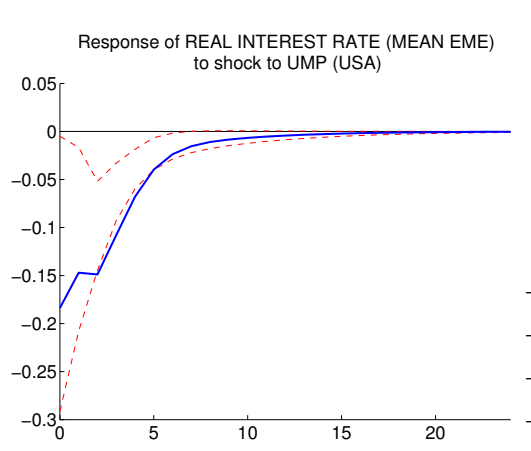

(b) real interest rate

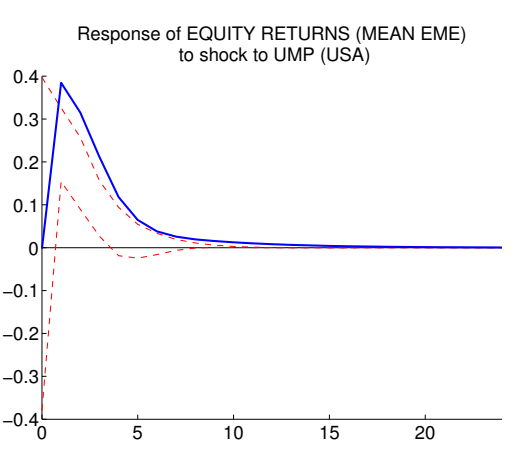

(c) equity returns

Figure 5: Responses of EME variables (mean) to U.S. UMP shock - model: FC II

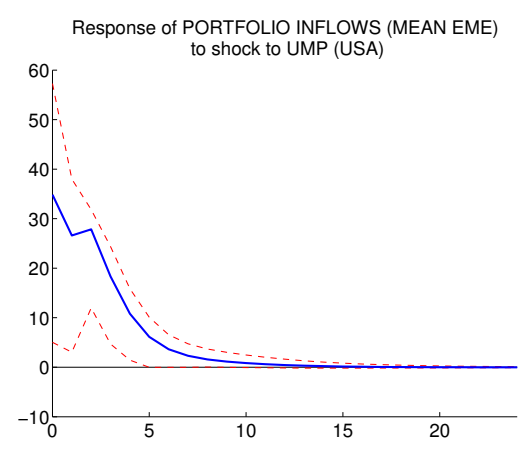

(a) portfolio inflows

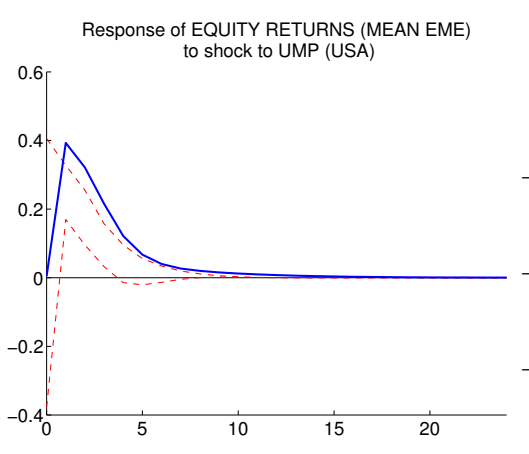

(b) equity returns

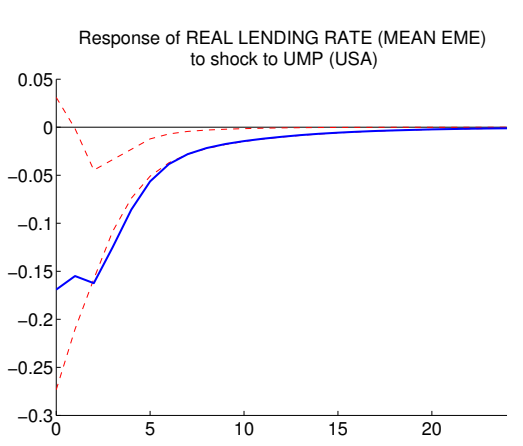

(c) real lending rate

Figure 6: Responses of EME variables (mean) to U.S. UMP shock - model: FC III

As stated in Section 2, several studies have established a link between U.S. UMP and bond flows (cf. Fratzscher et al., 2014, Koepke, 2014, among others). So far, we have presented results from empirical models where portfolio outflows - consisting of bond and equity flows - are the only possible transmission channel of U.S. UMP (cf. section 3.3). In order to assure that the portfolio flows have not been artificially imposed as the transmission channel of U.S. UMP by construction of the model and thus, to (indirectly) test Hypothesis 1, we re-estimate all models adding further variables in the vector $y_{i t}^{*}$ for the EMEs. For the model BC, we include foreign output growth, and for all the models for financial conditions we include either foreign output growth or U.S. equity returns in $y_{i t}^{*}$. In general, all our results remain qualitatively and 
quantitatively similar. ${ }^{23}$ Therefore, we can assume that most of the transmission of UMP goes through the portfolio flows. Our results give rise to the notion stated in Hypothesis 1: portfolio flows are indeed affected by UMP.

\subsection{Alternative specifications \& robustness}

In the following, we evaluate the impact of several of our choices concerning variables included or other specification decisions, on the results of our hypothesis tests. The IRF graphs of this section are available upon request from the authors.

Since reserves accumulation is a tool of monetary policy which EMEs' central banks actively use, as an alternative specification we re-estimate all models replacing the interest rate by foreign exchange reserves growth. A reserves' (growth) increase implies expansionary monetary policy. In response to the U.S. UMP shock, capital flows and equity returns rise, as in all models above, and foreign exchange reserve accumulation also increases, which implies the implementation of expansionary monetary policy. These results are in line with all of our previous findings. To check the robustness of this alternative specification, we control for exogenous commodity price inflation. Commodity prices may drive the accumulation of foreign currency since some of the countries in our sample are commodity exporters. Our results prove to be robust.

Furthermore, we follow Bowman et al. (2015) and Chen et al. (2015), and examine the response of long-term government bond yields in EMEs following the UMP shock. To do so, we replace real interest rates by long term yields in FC I. The remaining variables display similar IRFs as above. The mean response of long-term government bond yields first increases for two periods, and then significantly decreases for around 6 months. However, there is heterogeneity in the response of long-term yields for individual countries. While most of the countries in Europe find themselves with lower bond yields, the situation for Asia and Latin America is mixed. Israel and South Africa's government bond yields increase significantly.

The main results presented above are robust to one or several countries being dropped from the sample (the mean responses change quantitatively, but remain qualitatively the same). There are also no qualitative changes if the estimation is done using a post-Lehman sample, i.e. starting in November 2008. The results are not sensitive to the use of the industrial production growth instead of interpolated real GDP growth or to the use of the real effective exchange rate instead of the real bilateral USD exchange rate. Our results are also robust to including a second or third lag in the estimation.

Furthermore, we estimate a larger model which encompasses models FC I and FC II. We do so in order to make sure that we are not affected by an omitted-variable bias in our estimations. The results are quantitatively and qualitatively similar as the ones for the smaller model. The same holds true if a model that encompasses models FC II and FC III is estimated.

\footnotetext{
${ }^{23}$ The resulting graphs are available upon request.
} 
Finally, we evaluate the sensitivity of our results to the ordering of the variables in the Cholesky identification scheme. Recall that in the specifications discussed so far, part of the identification of the U.S. UMP shock was the assumption that the U.S. economy does not react instantaneously to shocks in any other country. We check the role of this assumption by switching from the implicit country-based ordering to a concept-based ordering of variables in the Cholesky scheme. Considering the $\mathrm{BC}$ model as an example, we order the variables such that real GDP for all countries is followed by U.S. inflation, U.S. capital outflows and then all EMEs' capital inflows. These variables are then followed by the U.S. UMP variables (Fed balance sheet and VIX) as well as all other variables of the system. ${ }^{24}$ In particular, this identification scheme allows for an instantaneous response of U.S. UMP to international capital flows. The results of this specification prove to be qualitatively and quantitatively the same as our previous results.

\section{Results for regions and EMEs' monetary policy response}

So far, the results shed light on the average IRFs over all the EMEs in our sample. Now, we go into detail to analyze if there is cross-sectional heterogeneity in our sample of countries. For instance, U.S. capital flows towards Europe may not be as large as towards Asia or Latin America, since European EMEs have tighter economic links to advanced European economies like Germany, France and the UK. Therefore the effects on the real variables and on financial conditions may vary across regions. Furthermore, the differentiation of our results according to the countries' exchange rate regime choice is necessary for testing our Hypothesis 3.

\subsection{Results for regions and country groups}

The EMEs we analyze are grouped by geographic region. Figures $7-12$ show the IRFs of the models FC I and III for Latin America (Brazil, Chile, Colombia, Mexico, Peru), ${ }^{25}$ Europe (Hungary, Poland, Russia, Turkey) and Asia (India, Indonesia, Korea, Malaysia, Philippines, Singapore, Thailand). ${ }^{26}$

Figure 7 and 8 indicate that Latin American countries receive, on average, around 80 million USD in capital inflows after a UMP shock in the U.S. The inflows remain positive and significant for over half a year. In FC I, the exchange rate appreciates due to this inflow, and the real interest rate significantly decreases. This suggests that Latin American central banks, on average, reacted to the capital inflows by decreasing their policy rate, in an attempt to deflect the flows and avoid the currency depreciation. Furthermore, FC III indicates that the financial conditions are also affected: equity returns significantly increase and the real lending rate significantly decreases.

\footnotetext{
${ }^{24}$ Note that the specific ordering of the variables after the shock does not have any consequence on its identification.

${ }^{25}$ Note that, once again, Argentina is not considered in the calculation of the regional mean since it is a large outlier.

${ }^{26}$ Israel and South Africa are not considered since they cannot be geographically attributed to the other regions.
} 


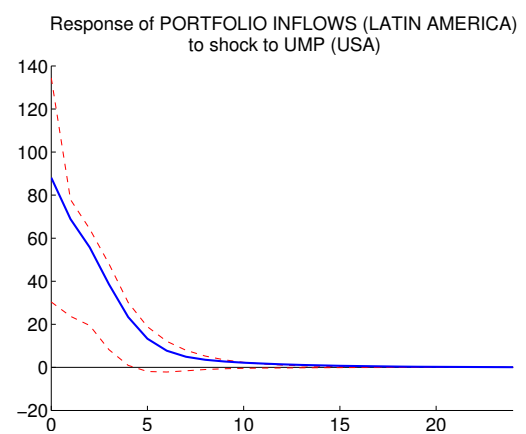

(a) portfolio inflows

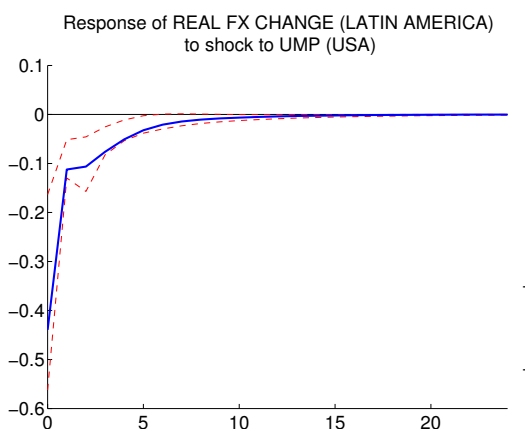

(b) real fx rate change

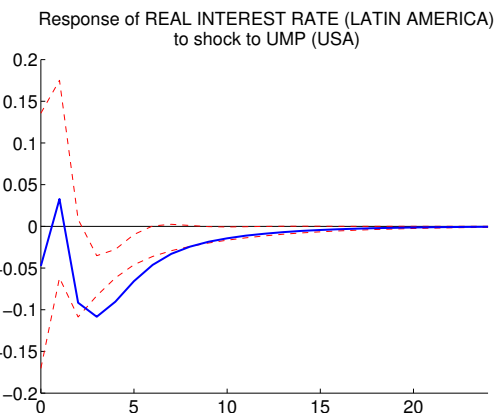

(c) real interest rate

Figure 7: Responses of Latin America (mean) to U.S. UMP shock - model: FC I

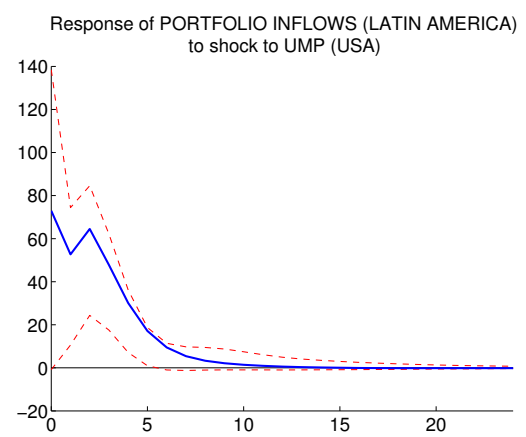

(a) portfolio inflows

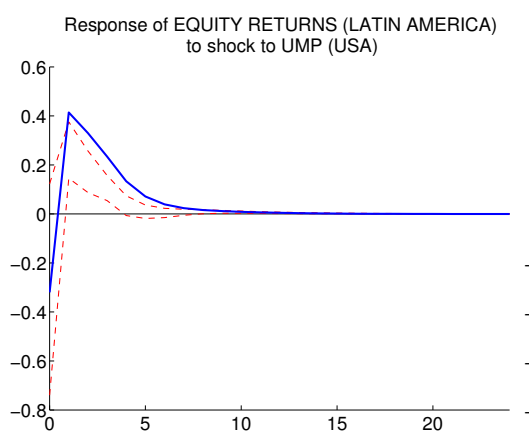

(b) equity returns

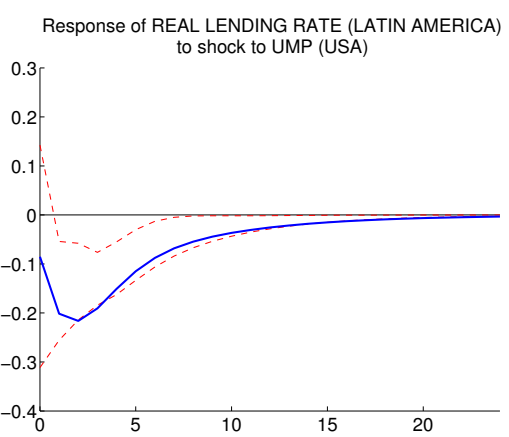

(c) real lending rate

Figure 8: Responses of Latin America (mean) to U.S. UMP shock - model: FC III

Asia's IRFs, depicted in Figures 9 and 10, look very similar to the ones for Latin America. Capital inflows are slightly lower in FC I, showing their peak 2 months after the shock and reaching around 60 million USD; in FC III the inflows are much lower at about 20 million USD. Furthermore, real exchange rate and real interest rate display a similar response as Latin America, as do equity returns and real lending rate, indicating that capital inflows affect the exchange rate, policy rate and financial conditions overall.

Finally, the picture is similar in Europe. The results depicted in Figures 11 and 12 show that Europe receives less capital inflows on average with around 20 million USD. Even though its currencies appreciate after the shock, interest rates do not seem to react much: at first there is a (slightly) significant decrease which is immediately followed by a small significant increase. However, financial conditions seem to be affected by the UMP shock in the U.S.: equity returns increase and lending rates fall. 


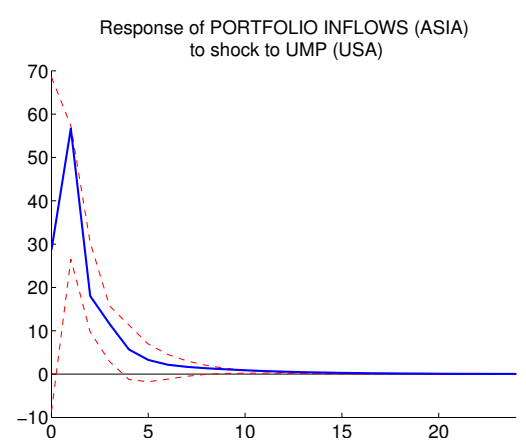

(a) portfolio inflows

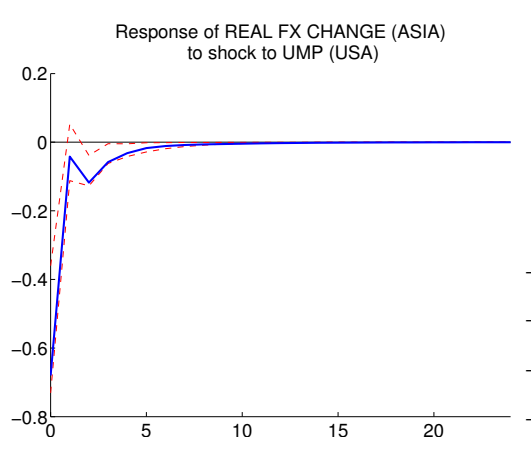

(b) fx rate change

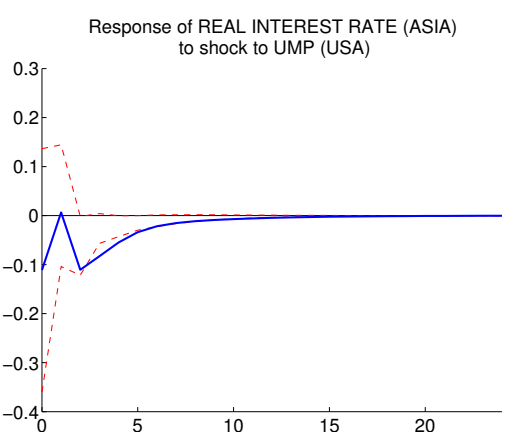

(c) real interest rate

Figure 9: Responses of Asia (mean) to U.S. UMP shock - model: FC I

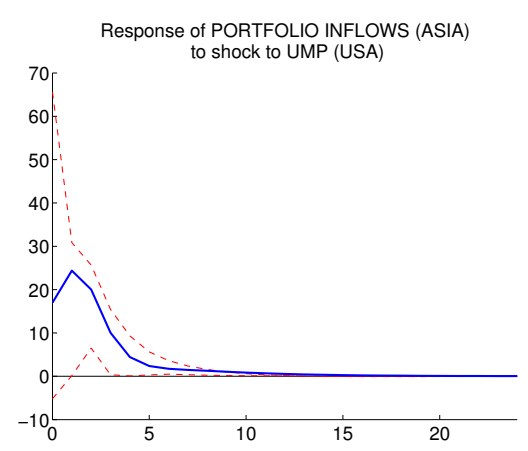

(a) portfolio inflows

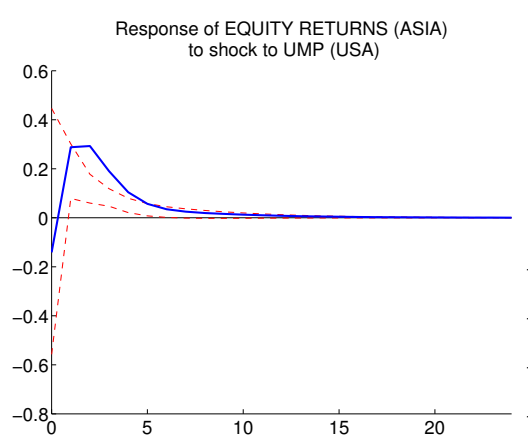

(b) equity returns

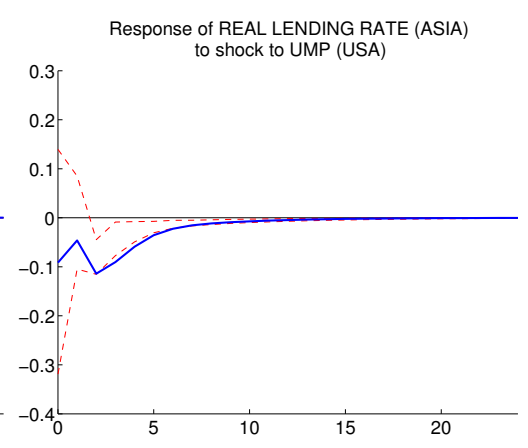

(c) real lending rate

Figure 10: Responses of Asia (mean) to U.S. UMP shock - model: FC III

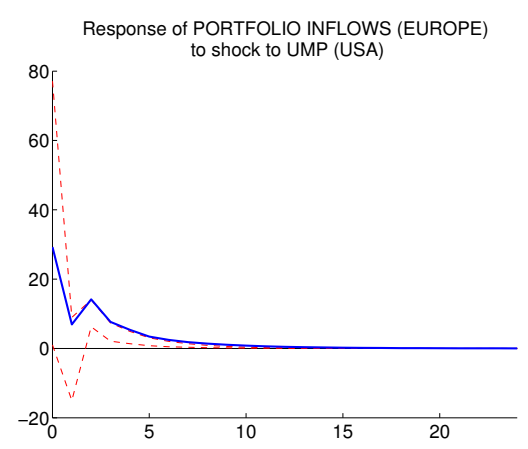

(a) portfolio inflows

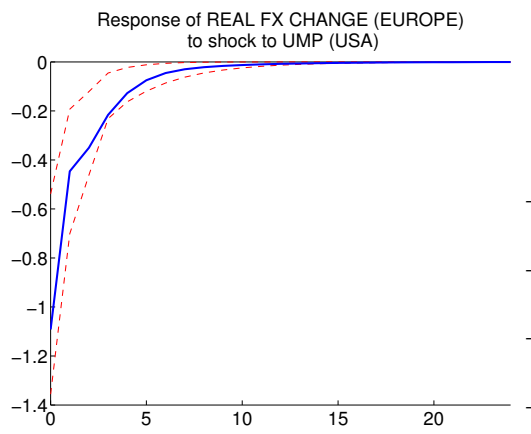

(b) real fx rate change

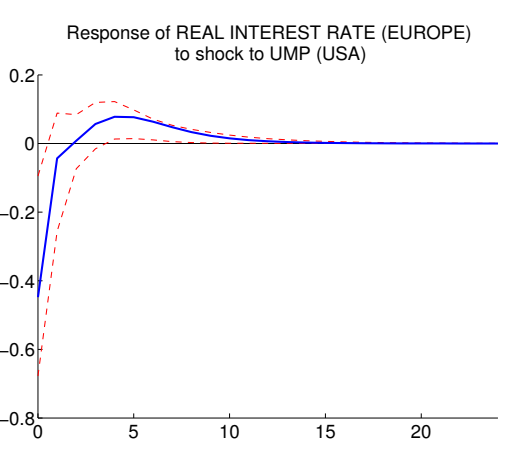

(c) real interest rate

Figure 11: Responses of Europe (mean) to U.S. UMP shock - model: FC I

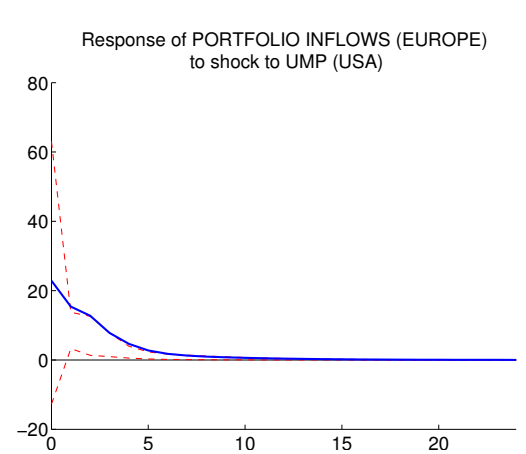

(a) portfolio inflows

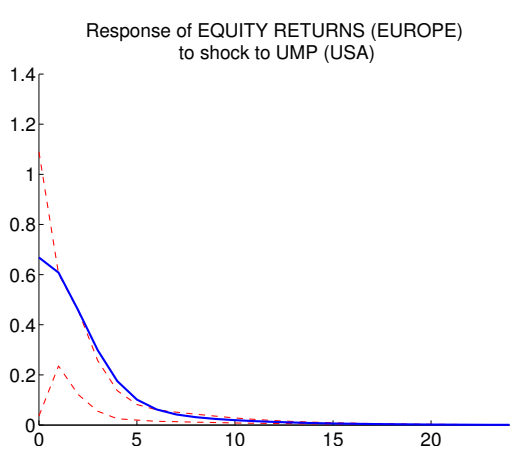

(b) equity returns

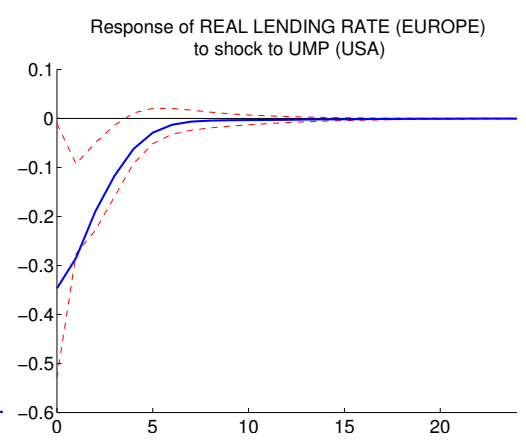

(c) real lending rate

Figure 12: Responses of Europe (mean) to U.S. UMP shock - model: FC III 


\subsection{Free floaters, the dilemma and the trilemma}

Previous sections have addressed the reaction of real and financial variables in EMEs to a UMP shock in the U.S. Our results so far provide evidence in favor of Hypotheses 1 and 2, in line with findings by Bruno and Shin (2015a) and Passari and Rey (2015) for conventional monetary policy and international banking flows.

In addition, average impulse response functions indicate that monetary authorities in EMEs react to capital inflows with a mirroring policy. One likely explanation is the aim to deflect the capital inflows in order to avoid or to calm an appreciation of the currency ("fear of floating"). This average reaction alone is not yet an indication for Hypothesis 3 and the dilemma vs. trilemma debate. Recall that Rey (2013) argues that countries face a dilemma: they can either choose monetary policy autonomy or free capital flows, independently of their exchange rate regime. If, however, we find that only exchange rate fixing countries react to expansionary U.S. UMP shocks with a monetary expansion of their own, this would be well in line with the classical trilemma.

Therefore, we look specifically at the reaction of monetary policy in those sample countries which have a floating exchange rate regime and, thus, should have monetary policy independence if the trilemma view holds. An indication in favor of Hypothesis 3 would be a decrease in the policy interest rate after increasing capital inflows for these floating countries. Figures 13, 14 and 15 show the IRFs for the models BC, FC I and FC II for the group of free floaters according to Klein and Shambaugh's de facto classification of countries' prevailing exchange rate regimes. ${ }^{27}$ Thereby, we consider a country to be a free floater if it has not had an official peg between 2008 and 2014. The countries in this list are Brazil, Chile, Mexico, Korea, the Philippines, Hungary, Poland, Turkey, Israel and South Africa. ${ }^{28}$ These figures show that monetary policy in countries with a floating exchange rate regime reacts significantly to the U.S. UMP shock.

Figures 16, 17 and 18, on the other hand, show the IRFs for countries with a peg. ${ }^{29}$ Similarly to the floating countries, in most specifications a mirroring domestic policy reaction in response to a U.S. UMP shock is found. Surprisingly, however, the result for the pegging countries is far less robust and significant across specifications than for the floating countries. One possible explanation is that this group of countries is less affected by U.S. portfolio flows than the floating countries, for non-exchange rate related reasons.

\footnotetext{
${ }^{27}$ This classification is based on Klein and Shambaugh (2008) and can be found on Jay C. Shambaugh's homepage.

${ }^{28}$ Alternatively, we have used the IMF's de jure classification. The resulting group is slightly different, but the results regarding the monetary policy reaction in floating countries are very similar.

${ }^{29}$ This group is formed by the rest of the countries in our sample, excluding Argentina (which is an outlier, see Section 4.3.1).
} 


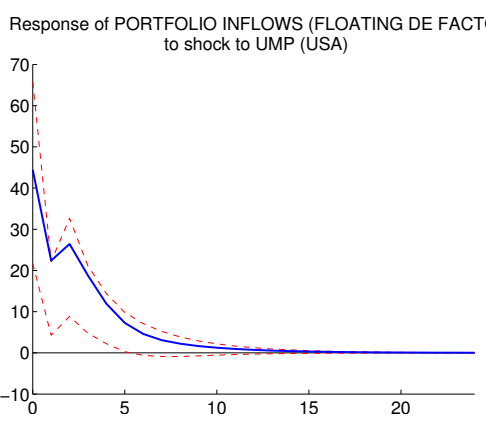

(a) portfolio inflows

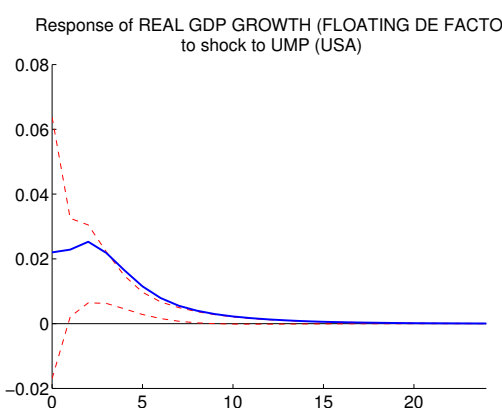

(b) real gdp growth

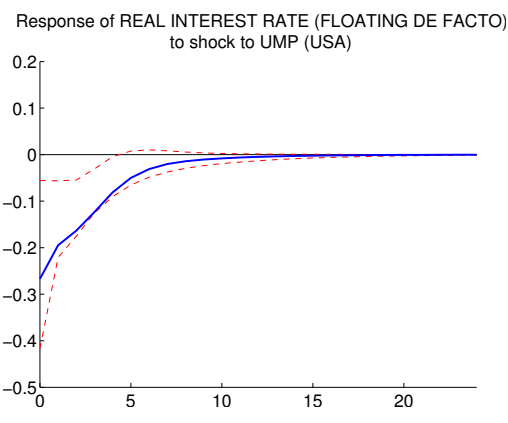

(c) real interest rate

Figure 13: Responses of "Free Floaters" (mean) to U.S. UMP shock - model: Business Cycle

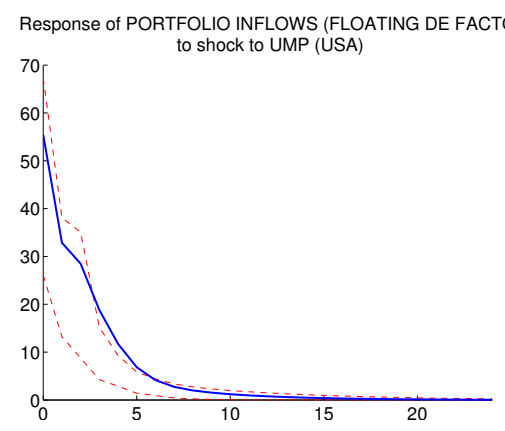

(a) portfolio inflows

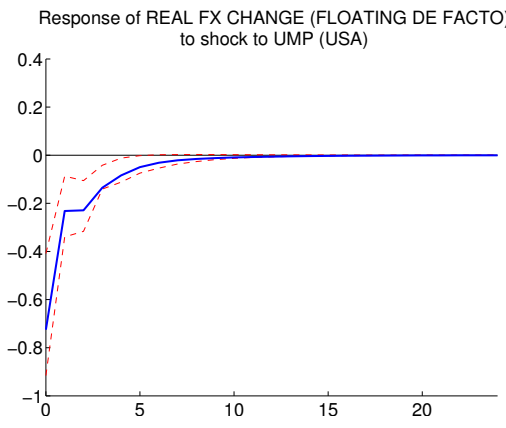

(b) real fx rate change

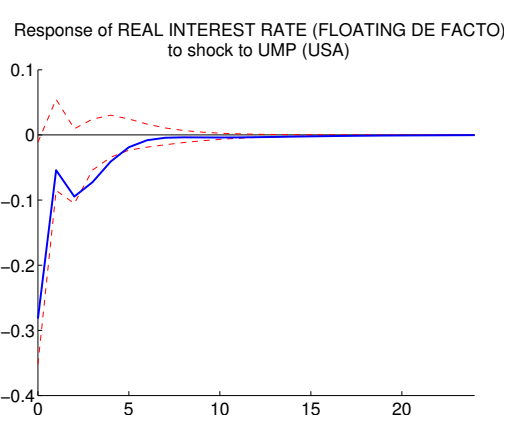

(c) real interest rate

Figure 14: Responses of "Free Floaters" (mean) to U.S. UMP shock - model: FC I

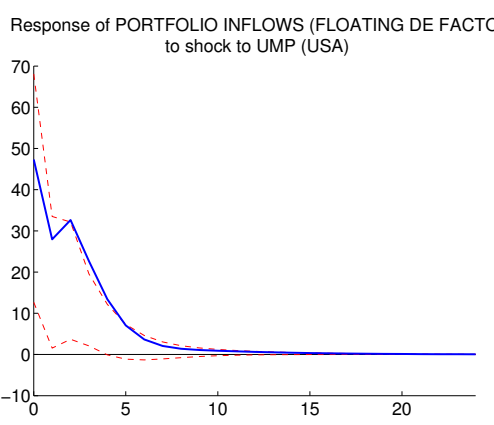

(a) portfolio inflows

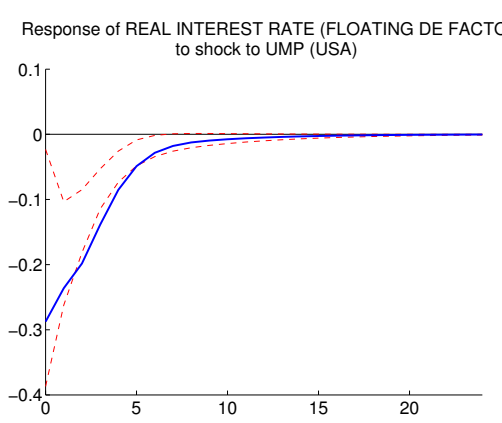

(b) real interest rate

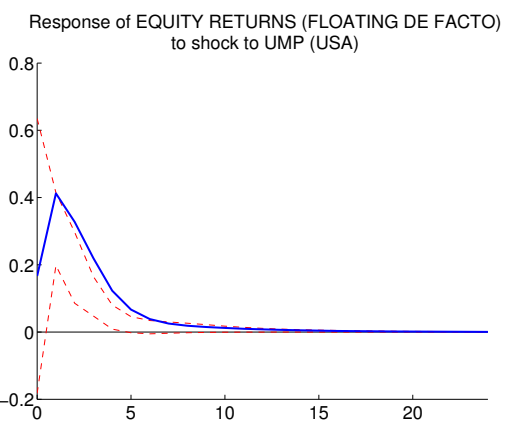

(c) equity returns

Figure 15: Responses of "Free Floaters" (mean) to U.S. UMP shock - model: FC II 


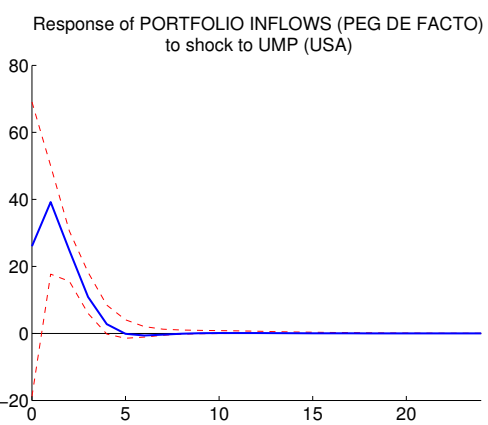

(a) portfolio inflows

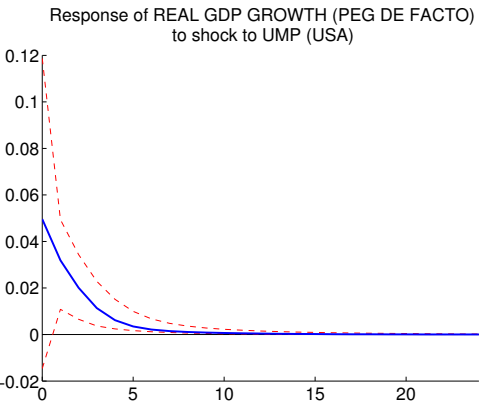

(b) real gdp growth

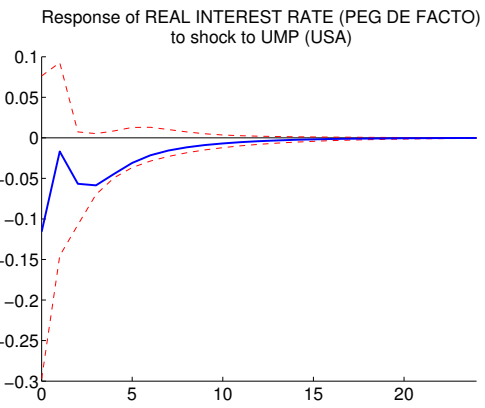

(c) real interest rate

Figure 16: Responses of pegging countries (mean) to U.S. UMP shock - model: Business Cycle

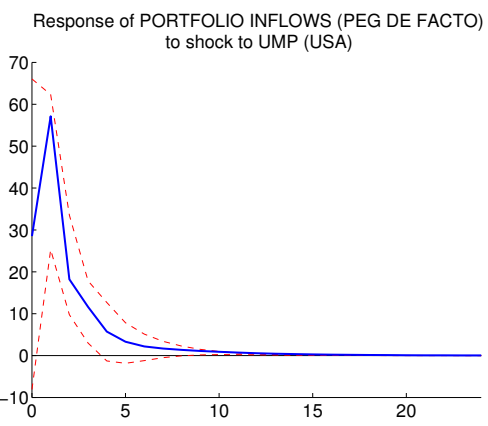

(a) portfolio inflows

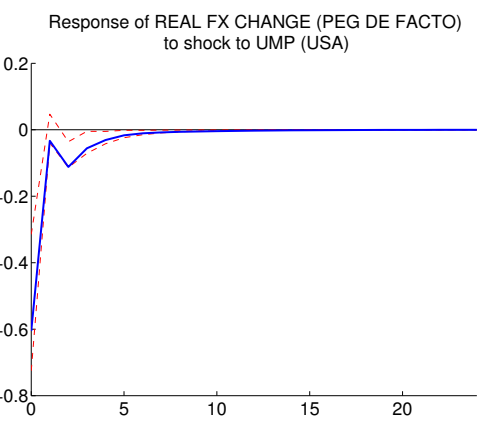

(b) real fx rate change

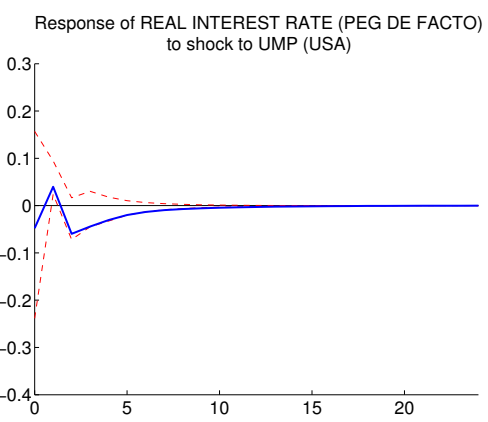

(c) real interest rate

Figure 17: Responses of pegging countries (mean) to U.S. UMP shock - model: FC I

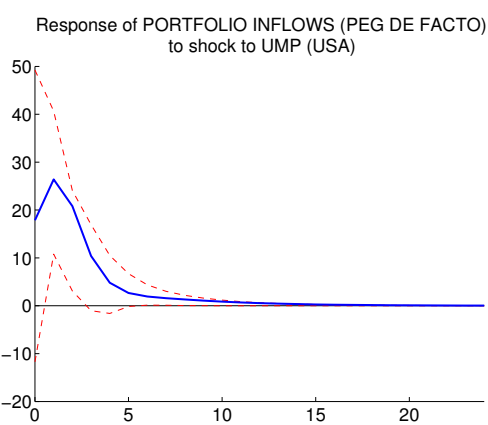

(a) portfolio inflows

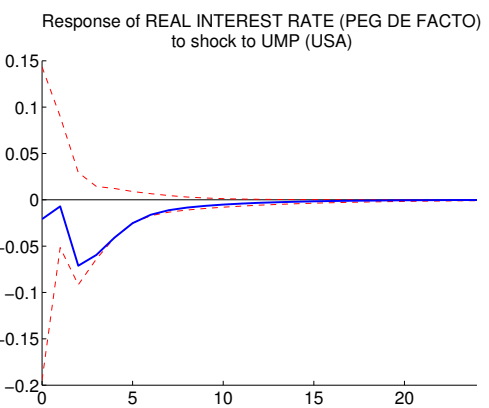

(b) real interest rate

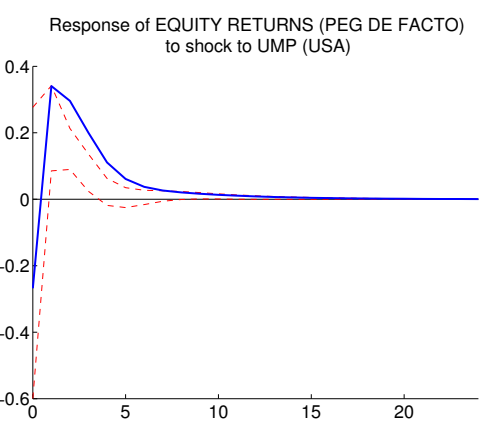

(c) equity returns

Figure 18: Responses of pegging countries (mean) to U.S. UMP shock - model: FC II 


\section{Conclusion}

A growing literature stresses the importance of the "global financial cycle", a common movement in asset prices and credit conditions globally, for emerging market economies (EMEs). One of the key drivers of this global cycle is supposed to be monetary policy in the U.S., which is transmitted through international capital flows. The debate has been boosted by the supposed connection between the implementation of UMP measures by the Federal Reserve and large and volatile capital flows into EMEs after the recent financial crisis.

In this paper, we contribute to this discussion by empirically investigating whether U.S. unconventional monetary policy is related to financial conditions in EMEs, and, whether portfolio flows are an important channel of transmission. To that aim, we set up a structural global vector autoregressive model that allows for a clear identification of a UMP shock and takes economic interlinkages between EMEs into account. In particular, we provide answers to the following questions: First, does U.S. UMP affect portfolio outflows from the U.S. and portfolio inflows into EMEs? Second, does U.S. UMP - through portfolio flows - drive financial conditions in EMEs? Finally, has UMP - through portfolio flows - a significant effect on EMEs' monetary policy?

Our main results show that a U.S. UMP shock related to the Fed's large-scale asset purchases significantly increases portfolio outflows from the U.S. for almost six months. In the EMEs, this is associated with portfolio inflows. Along with the increase in inflows, real output growth and equity returns rise, the real exchange rate appreciates and the real lending rate decreases. Hence, we find evidence suggesting that U.S. UMP affects portfolio flows and, through these flows, drives financial conditions in EMEs. Furthermore, regarding domestic monetary policy, we find that EMEs react by decreasing their policy rate in response to the U.S. shock, regardless of their exchange rate regime. This last finding is in line with a monetary policy "dilemma" instead of a "trilemma".

Further research on the effects of U.S. UMP on EMEs' real variables, financial conditions and monetary policy stance could explore the following aspects. Given our identification strategy and sample period, we did not analyze the effects of policy uncertainty about the end of UMP (e.g., the so-called "taper tantrum"). Future research might explore how this uncertainty affects portfolio flows between the U.S. and EMEs. Furthermore, in the spirit of the dilemma vs trilemma debate, it might be interesting to assess whether capital controls have an impact on the quantity of portfolio inflows and on their effects on financial conditions, as well as on the relationship between U.S. UMP and EMEs' monetary policy autonomy. 


\section{References}

Ahmed, S. and A. Zlate (2014): Capital flows to emerging market economies: A brave new world?, Journal of International Money and Finance, 48, 221-248.

Aizenman, J., M. Binici and M.M. Hutchison (2014): The Transmission of Federal Reserve Tapering News to Emerging Financial Markets, NBER Working Papers No. 19980, National Bureau of Economic Research.

Bekaert, G., M. Hoerova and M. Lo Duca (2013): Risk, uncertainty and monetary policy, Journal of Monetary Economics, 60(7), 771-788.

Bertaut, C. and R. Judson (2014): Estimating U.S. Cross-Border Securities Positions: New Data and New Methods, International Finance Discussion Papers No. 1113, Board of Governors of the Federal Reserve System.

Bertaut, C.C. and R.W. Tryon (2007): Monthly Estimates of U.S. Cross-border Securities Positions, International Finance Discussion Papers No. 910, Board of Governors of the Federal Reserve System.

Boeckx, J., M. Dossche and G. Peersman (2014): Effectiveness and Transmission of the ECB's Balance Sheet Policies, CESifo Working Paper Series No. 4907, CESifo Group Munich.

Bowman, D., J.M. Londono and H. Sapriza (2015): U.S. unconventional monetary policy and transmission to emerging market economies, Journal of International Money and Finance, 55, $27-59$.

Bruno, V. and H.S. Shin (2015a): Capital flows and the risk-taking channel of monetary policy, Journal of Monetary Economics, 71, 119-132.

Bruno, V. and H.S. Shin (2015b): Cross-Border Banking and Global Liquidity, Review of Economic Studies, 82(2), 535-564.

Chen, Q., A. Filardo, D. He and F. Zhu (2015): Financial crisis, US unconventional monetary policy and international spillovers, Journal of International Money and Finance, forthcoming.

Chow, G.C. and A. Lin (1971): Best Linear Unbiased Interpolation, Distribution, and Extrapolation of Time Series by Related Series, The Review of Economics and Statistics, 53(4), $372-75$.

Christiano, L.J., M. Eichenbaum and C.L. Evans (1999): Monetary policy shocks: What have we learned and to what end?, in: J. B. Taylor and M. Woodford (Eds.), Handbook of Macroeconomics: Elsevier, Vol. 1, Part A, Chapter 2, pp. 65-148.

Curcuru, S.E., T. Dvorak and F.E. Warnock (2010): Decomposing the U.S. external returns differential, Journal of International Economics, 80(1), 22-32.

Dahlhaus, T. and G. Vasishtha (2014): The Impact of U.S. Monetary Policy Normalization on Capital Flows to Emerging-Market Economies, Working Paper No. 2014-53, Bank of Canada.

Dees, S., F.d. Mauro, M.H. Pesaran and L.V. Smith (2007): Exploring the international linkages of the euro area: a global VAR analysis, Journal of Applied Econometrics, 22(1), 1-38. 
Eichengreen, B. and P. Gupta (2014): Tapering talk: the impact of expectations of reduced federal reserve security purchases on emerging markets, Policy Research Working Paper Series No. 6754, The World Bank.

Eickmeier, S. and T. Ng (2015): How do US credit supply shocks propagate internationally? A GVAR approach, European Economic Review, 74, 128-145.

Forbes, K.J. and F.E. Warnock (2012): Capital flow waves: Surges, stops, flight, and retrenchment, Journal of International Economics, 88(2), 235-251.

Fratzscher, M. (2012): Capital flows, push versus pull factors and the global financial crisis, Journal of International Economics, 88(2), 341-356.

Fratzscher, M., M. Lo Duca and R. Straub (2013): On the international spillovers of US quantitative easing, Working Paper Series No. 1557, European Central Bank.

Fratzscher, M., M. Lo Duca and R. Straub (2014): ECB Unconventional Monetary Policy Actions: Market Impact, International Spillovers and Transmission Channels, mimeo.

Fry, R. and A. Pagan (2007): Some Issues in Using Sign Restrictions for Identifying Structural VARs, NCER Working Paper Series No. 14, National Centre for Econometric Research.

Gambacorta, L., B. Hofmann and G. Peersman (2014): The Effectiveness of Unconventional Monetary Policy at the Zero Lower Bound: A Cross-Country Analysis, Journal of Money, Credit and Banking, 46(4), 615-642.

Georgiadis, G. (2015a): Determinants of global spillovers from US monetary policy, Journal of International Money and Finance, forthcoming.

Georgiadis, G. (2015b): Examining asymmetries in the transmission of monetary policy in the euro area: Evidence from a mixed cross-section global VAR model, European Economic Review, 75, 195-215.

Gourinchas, P.O. and M. Obstfeld (2012): Stories of the Twentieth Century for the Twenty-First, American Economic Journal: Macroeconomics, 4(1), 226-65.

Hanlon, M., E.L. Maydew and J.R. Thornock (2015): Taking the Long Way Home: U.S. Tax Evasion and Offshore Investments in U.S. Equity and Debt Markets, The Journal of Finance, 70(1), 257-287.

International Monetary Fund (2013): Global Impact and Challenges of Unconventional Monetary Policies - Background Paper, IMF Policy Paper, Washington, DC: International Monetary Fund.

Joyce, M., D. Miles, A. Scott and D. Vayanos (2012): Quantitative Easing and Unconventional Monetary Policy - An Introduction, Economic Journal, 122(564), F271-F288.

Klein, M.W. and J.C. Shambaugh (2008): The dynamics of exchange rate regimes: Fixes, floats, and flips, Journal of International Economics, 75(1), 70-92.

Koepke, R. (2014): Fed policy expectations and portfolio flows to emerging markets, Institute of International Finance Working Paper, Institute of International Finance. 
Lim, J.J., S. Mohapatra and M. Stocker (2014): Tinker, taper, QE, bye? The effect of quantitative easing on financial flows to developing countries, Policy Research Working Paper Series No. 6820, The World Bank.

Lo Duca, M., G. Nicoletti and A. Vidal Martinez (2014): Global corporate bond issuance: what role for US quantitative easing?, Working Paper Series No. 1649, European Central Bank.

Miranda Agrippino, S. and H. Rey (2014): World Asset Markets and the Global Financial Cycle, mimeo.

Moore, J., S. Nam, M. Suh and A. Tepper (2013): Estimating the Impacts of U.S. LSAPs on Emerging Market Economies' Local Currency Bond Markets, Federal Reserve Bank of New York Staff Report No. 595, Federal Reserve Bank of New York.

Passari, E. and H. Rey (2015): Financial Flows and the International Monetary System, The Economic Journal, 125(584), 675-698.

Rai, V. and L. Suchanek (2014): The Effect of the Federal Reserve's Tapering Announcements on Emerging Markets, Working Paper No. 2014-50, Bank of Canada.

Rey, H. (2013): Dilemma not Trilemma: the Global Financial Cycle and Monetary Policy Independence, Proceedings of the Economic Policy Symposium at Jackson Hole, Federal Reserve Bank of Kansas City.

Shin, H.S. (2013): The second phase of global liquidity and its impact on emerging economies, in: Remarks at 2013 Federal Reserve Bank of San Francisco Asia Economic Policy Conference.

Tillmann, P. (2014): Unconventional Monetary Policy and the Spillovers to Emerging Markets, Working Paper No. 18/2014, Hong Kong Institute for Monetary Research.

Turner, P. (2014): The global long-term interest rate, financial risks and policy choices in EMEs, BIS Working Papers No. 441, Bank for International Settlements. 


\section{Appendix}

\section{A Data and sources}

Table 2: Data construction and sources

\begin{tabular}{|c|c|}
\hline Variable & Construction and source \\
\hline Real equity returns & $\begin{array}{l}\text { Difference between logs of the MSCI equity index and the consumer price index. } \\
\text { Sources: Datastream and St.Louis Fred database (U.S. CPI). }\end{array}$ \\
\hline Real output growth & $\begin{array}{l}\text { Monthly real GDP is obtained by interpolating quarterly real GDP with an index } \\
\text { of industrial production using the method of Chow and Lin (1971). Real output } \\
\text { growth is first log difference of real GDP. Sources: Datastream and St.Louis } \\
\text { Fred database (U.S. GDP / IP). }\end{array}$ \\
\hline Inflation rate & $\begin{array}{l}\text { First difference of the log of monthly consumer price index (CPI). Source: } \\
\text { Datastream. }\end{array}$ \\
\hline Fed balance sheet & In log. Source: Federal Reserve Bank of St. Louis database. \\
\hline VIX & In levels. Source: Federal Reserve Bank of St. Louis database. \\
\hline Real exchange rate change & $\begin{array}{l}\text { Nominal exchange rates } e_{t} \text { are from Datastream. Real exchange rates are } \\
\text { calculated using the following formula } \Delta\left(r_{t}\right)=\Delta\left(e_{t}+c p i_{t}^{U S}-c p i_{t}\right) * 100\end{array}$ \\
\hline Real interest rates & $\begin{array}{l}\text { Monetary policy rates } i_{t} \text { are from Datastream. Exact definition depends on } \\
\text { policy measures of the respective country (target rate, policy rate). A detailed } \\
\text { list of the individual rates can be obtained upon request. Rates are converted to } \\
\text { annualized real terms by the following formula } i_{t}-\Delta\left(\ln \left(C P I_{t}\right)\right) * 12 * 100\end{array}$ \\
\hline Real lending rates & $\begin{array}{l}\text { Lending rates } l_{t} \text { are from the IMF IFS database. Rates are converted to annual- } \\
\text { ized real terms by the following formula } l_{t}-\Delta\left(\ln \left(C P I_{t}\right)\right) * 12 * 100\end{array}$ \\
\hline Real effective exchange rates & $\begin{array}{l}\text { Indices of real effective exchange rates from the Bank of International Settle- } \\
\text { ments are obtained from Datastream. }\end{array}$ \\
\hline $\begin{array}{l}\text { Foreign exchange reserves } \\
\text { growth }\end{array}$ & Difference of the $\log$ of the fx reserves. Source: IMF IFS database. \\
\hline $\begin{array}{l}\text { Long-term government bond } \\
\text { yields }\end{array}$ & Source: Datastream. \\
\hline Commodity price inflation & $\begin{array}{l}\text { First difference of the log of the commodity price index. Source: IMF IFS } \\
\text { database. }\end{array}$ \\
\hline
\end{tabular}




\section{B Additional figures}

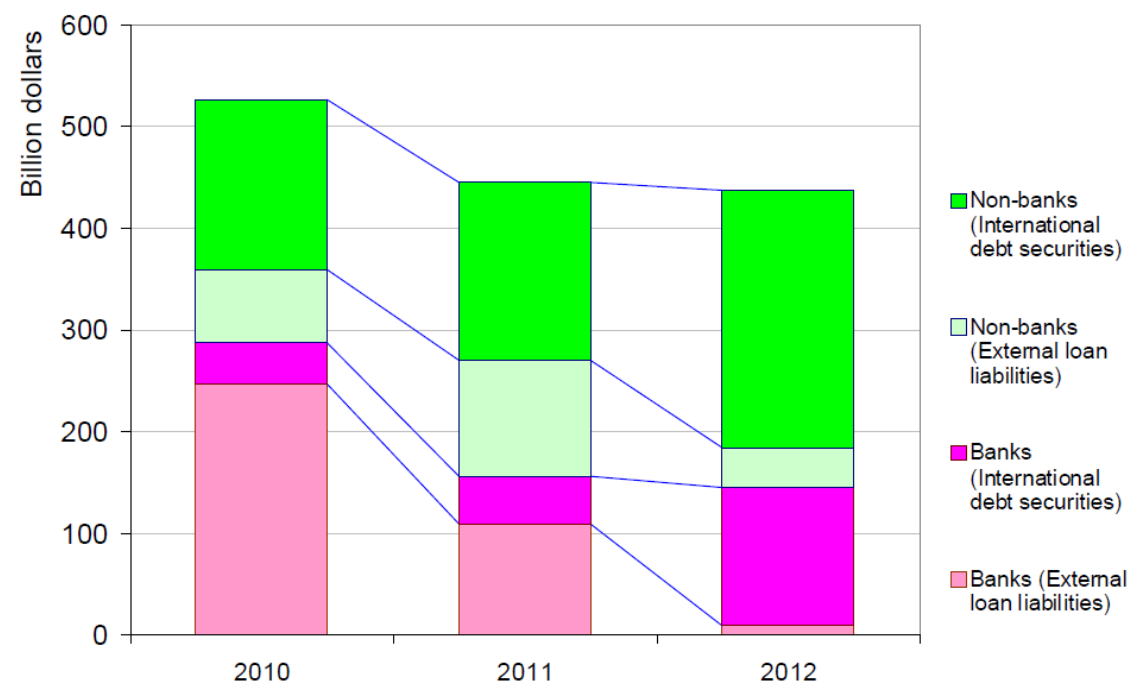

Figure 19: Net "external” financing of emerging economies. Source: Shin (2013), Turner (2014).

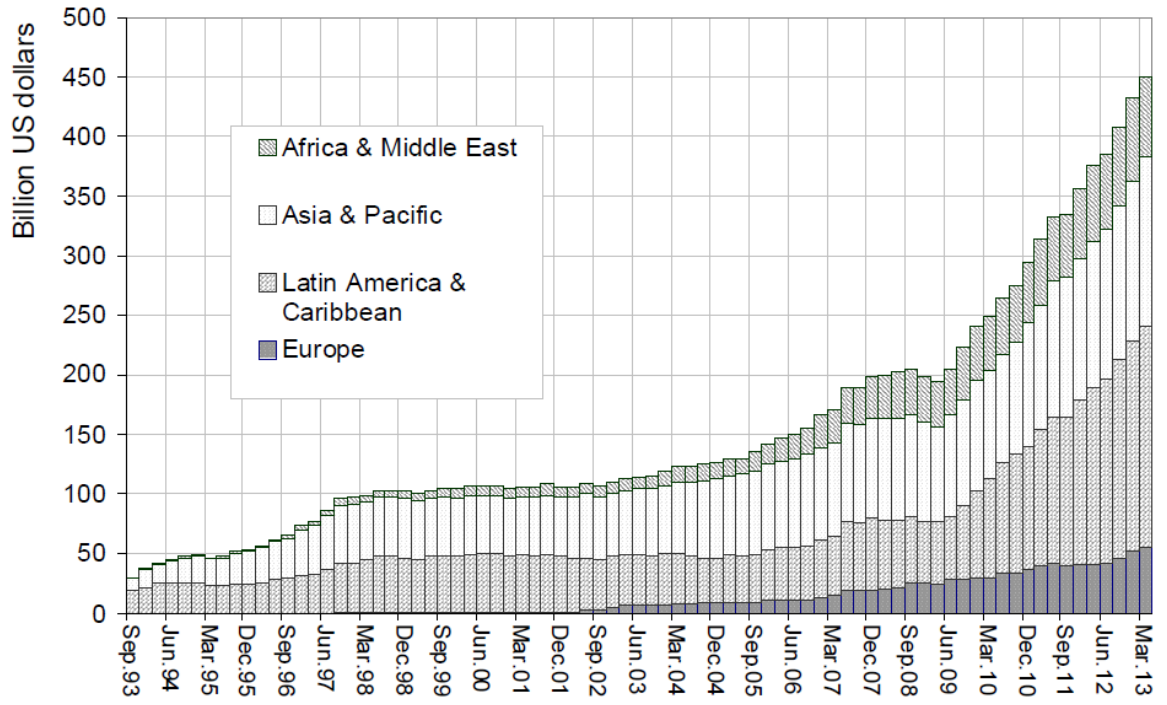

Figure 20: Non-financial corporate international debt securities outstanding for developing economies. Source: Shin (2013). 


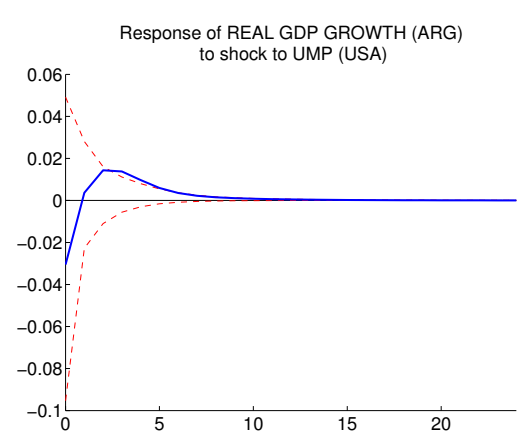

(a) real GDP growth

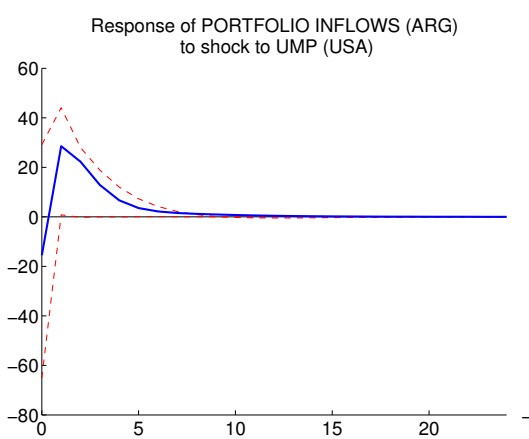

(b) portfolio inflows

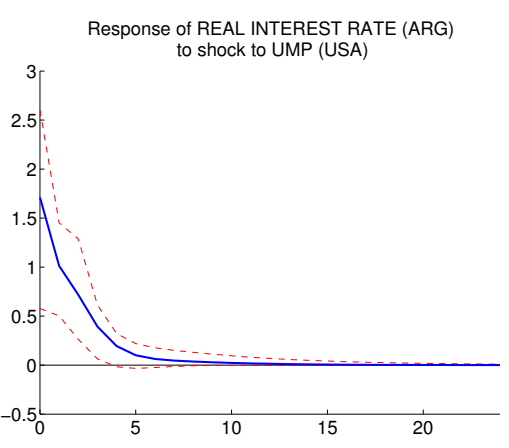

(c) real interest rate

Figure 21: Responses Argentina's variables to U.S. UMP shock - model: Business Cycle

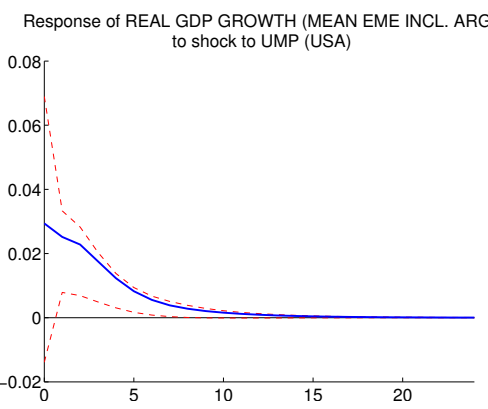

(a) real GDP growth

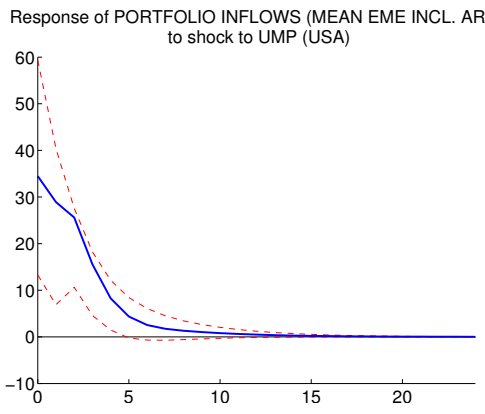

(b) portfolio inflows

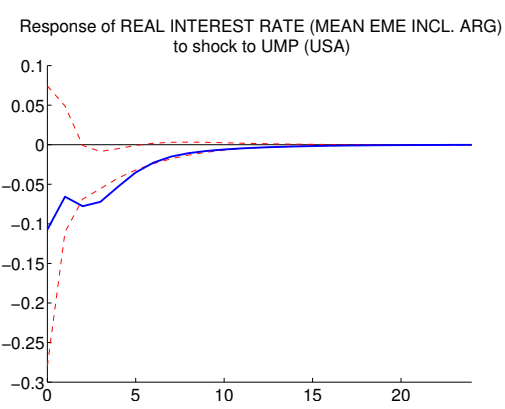

(c) real interest rate

Figure 22: Responses of EME variables (mean including Argentina) to U.S. UMP shock - model: Business Cycle 


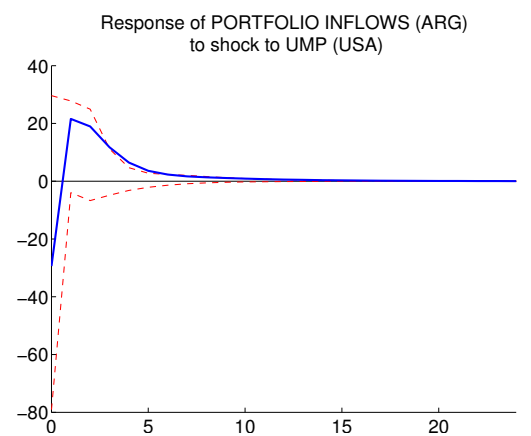

(a) portfolio inflows

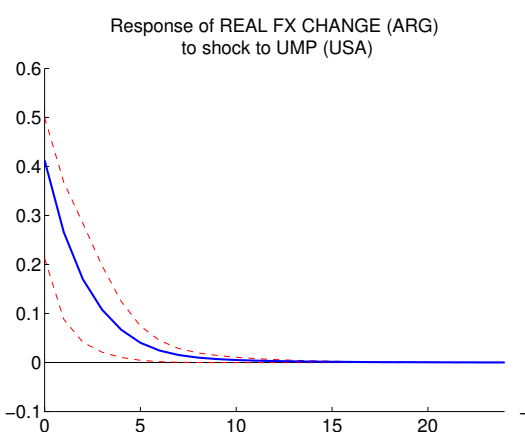

(b) real fx change

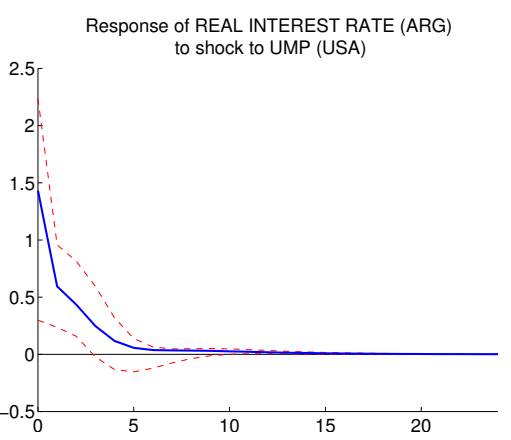

(c) real interest rate

Figure 23: Responses Argentina's variables to U.S. UMP shock - model: FC I

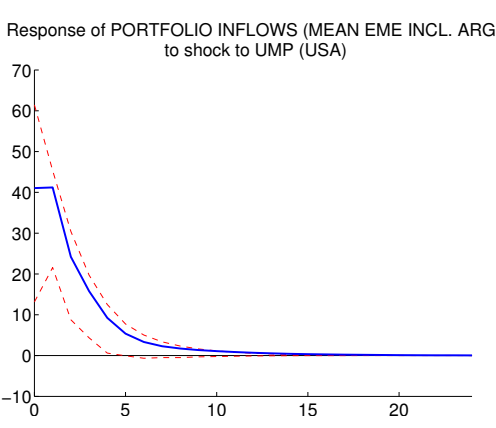

(a) portfolio inflows

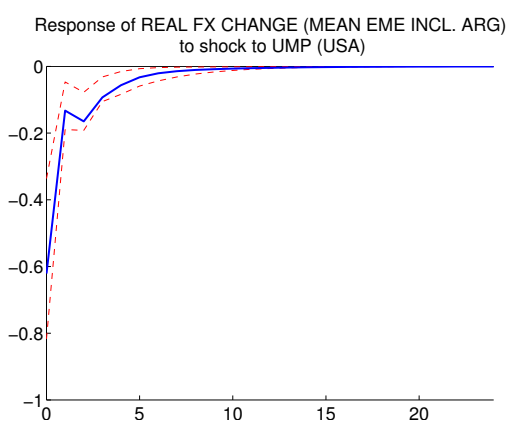

(b) real fx change

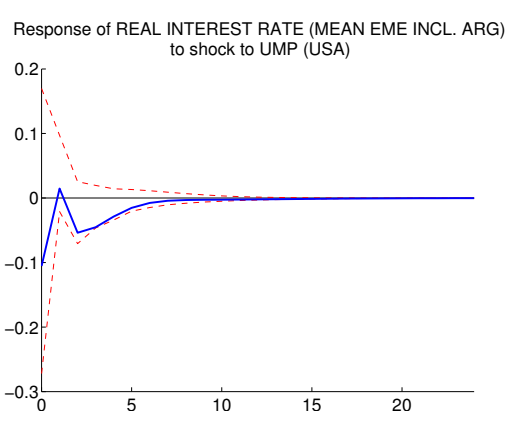

(c) real interest rate

Figure 24: Responses of EME variables (mean) to U.S. UMP shock - model: FC I

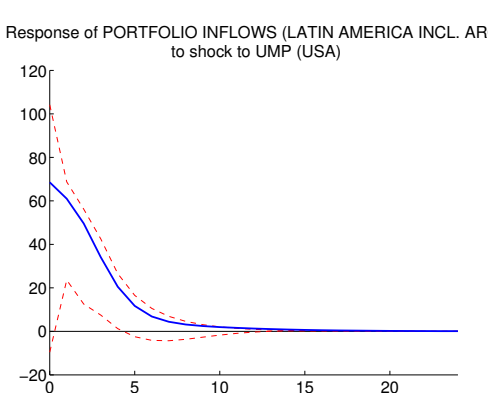

(a) portfolio inflows

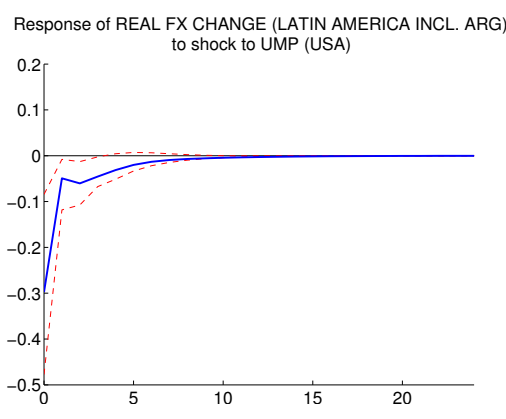

(b) real fx rate change

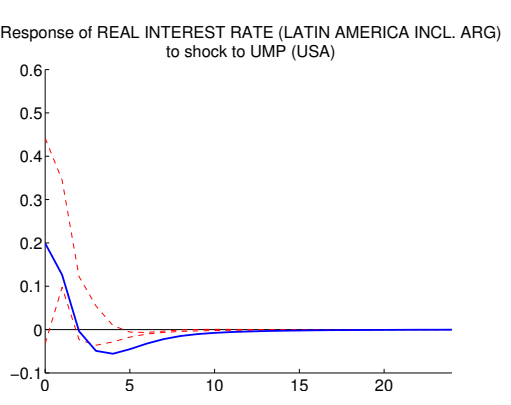

(c) real interest rate

Figure 25: Responses of Latin America (mean including Argentina) to U.S. UMP shock - model: FC I 


\section{Diskussionsbeiträge - Fachbereich Wirtschaftswissenschaft - Freie Universität Berlin Discussion Paper - School of Business and Economics - Freie Universität Berlin}

2015 erschienen:

2015/1 GÖRLITZ, Katja und Christina GRAVERT

The effects of increasing the standards of the high school curriculum on school dropout

Economics

2015/2 BÖNKE, Timm und Clive WERDT

Charitable giving and its persistent and transitory reactions to changes in tax incentives: evidence from the German Taxpayer Panel

Economics

2015/3 WERDT, Clive

What drives tax refund maximization from inter-temporal loss usage? Evidence from the German Taxpayer Panel

Economics

2015/4 FOSSEN, Frank M. und Johannes KÖNIG

Public health insurance and entry into self-employment

Economics

2015/5 WERDT, Clive

The elasticity of taxable income for Germany and its sensitivity to the appropriate model

Economics

2015/6 NIKODINOSKA, Dragana und Carsten SCHRÖDER

On the Emissions-Inequality Trade-off in Energy Taxation: Evidence on the German Car Fuel Tax

Economics

2015/7 GROß, Marcus; Ulrich RENDTEL; Timo SCHMID; Sebastian SCHMON und Nikos TZAVIDIS

Estimating the density of ethnic minorities and aged people in Berlin: Multivariate kernel density estimation applied to sensitive geo-referenced administrative data protected via measurement error

Economics

2015/8 SCHMID, Timo; Nikos TZAVIDIS; Ralf MÜNNICH und Ray CHAMBERS

Outlier robust small area estimation under spatial correlation

Economics

2015/9 GÖRLITZ, Katja und Marcus TAMM

Parenthood and risk preferences

Economics

2015/10 BÖNKE, Timm; Giacomo CORNEO und Christian WESTERMEIER

Erbschaft und Eigenleistung im Vermögen der Deutschen: eine Verteilungsanalyse

Economics 
2015/11 GÖRLITZ, Katja und Marcus TAMM

The pecuniary and non-pecuinary returns to voucher-financed training

Economics

2015/12 CORNEO, Giacomo

Volkswirtschaftliche Bewertung öffentlicher Investitionen

Economics

2015/13 GÖRLITZ, Katja und Christina Gravert

The effects of a high school curriculum reform on university enrollment and the choice of college major

Economics

2015/14 BÖNKE, Timm und Carsten SCHRÖDER

European-wide inequality in times of the financial crisis

Economics

2015/15 BÖNKE, Timm; Beate JOACHIMSEN und Carsten SCHRÖDER

Fiscal federalism and tax enforcement

Economics

2015/16 DEMMER, Matthias

Improving Profitability Forecasts with Information on Earnings Quality

FACTS

2015/17 HAAN, Peter und Victoria PROWSE

Optimal Social Assistance and Unemployment Insurance in a Life-cycle Model of Family Labor Supply and Savings

Economics

2015/18 CORNEO, Giacomo, Carsten SCHRÖDER und Johannes KÖNIG

Distributional Effects of Subsidizing Retirement Savings Accounts: Evidence from Germany

Economics

2015/19 BORGONI, Riccardo; Paola DEL BIANCO; Nicola SALVATI; Timo SCHMID und Nikos TZAVIDIS

Modelling the distribution of health related quality of life of advanced melanoma patients in a longitudinal multi-centre clinical trial using $M$-quantile random effects regression

Economics

2015/20 HELLER, C.-Philipp; Johannes JOHNEN und Sebastian SCHMITZ

Congestion Pricing: A Mechanism Design Approach

Economics

2015/21 BARTELS, Charlotte und Nico PESTEL

The Impact of Short- and Long-term Participation Tax Rates on Labor Supply

Economics

2015/22 JESSEN, Robin; Davud ROSTAM-AFSCHAR und Viktor STEINER

Getting the Poor to Work: Three Welfare Increasing Reforms for a Busy Germany Economics 
2015/23 BLAUFUS, Kay; Matthias BRAUNE; Jochen HUNDSDOERFER und Martin JACOB Does Legality Matter? : The Case of Tax Avoidance and Evasion FACTS

2015/24 RENDTEL, Ulrich

Warum im Zensus die Ergebnisse der Stichprobenmethode keine Benachteiligung der großen Gemeinden darstellen: eine Detektivarbeit

Economics

2015/25 RENDTEL, Ulrich

Is there a fade-away effect of initial nonresponse bias in EU-SILC?

Economics

2015/26 BÖNKE, Timm; Matthias GIESECKE und Holger LÜTHEN

The Dynamics of Earnings in Germany: Evidence from Social Security Records Economics

2015/27 GROß, Marcus und Ulrich RENDTEL

Kernel Density Estimation for Heaped Data

Economics

2015/28 DWENGER, Nadja; Frank M. FOSSEN und Martin SIMMLER

From financial to real economic crisis: Evidence from individual firm-bank relationships in Germany

Economics

2015/29 HACHULA, Michael und Sebastian HOFFMANN

The Output Effects of Commodity Price Volatility: Evidence from Exporting

Countries

Economics

2015/30 EICHFELDER, Sebastian; Frank HECHTNER und Jochen HUNDSDOERFER Formula apportionment: Factor allocation and tax avoidance

FACTS

2015/31 WAGNER, Julia

EBITDA-Vortrag - cui bono? : Eine Gesetzesevaluation auf Basis einer Mikrosimulation

FACTS

2015/32 HETSCHKO, Clemens und Malte PREUSS

Income in Jeopardy: How Losing Employment Affects the Willingness to Take Risks

Economics

2015/33 EICHFELDER, Sebastian und Mona LAU

Capitalization of capital gains taxes: (In)attention and turn-of-the-year returns Economics 
2015/34 HECHTNER, Frank

Tarifverwerfungen beim Zusammentreffen von Progressionsvorbehalt und Besteuerung außerordentlicher Einkünfte: Theoretische und empirische Befunde zu arbiträren Grenzsteuersatzverläufen FACTS 